\title{
Influence of Substrate Layer Thickness and Biochar on the Green Roof Capacity to Intercept Rainfall and Reduce Pollution in Runoff
}

\author{
Ruifang Meng', Qianqian Zhang ${ }^{1 *}$, Dongsheng Li², Huiwei Wang1 \\ ${ }^{1}$ Hebei and China Geological Survey Key Laboratory of Groundwater Remediation, Institute of Hydrogeology \\ and Environmental Geology, Chinese Academy of Geological Sciences, Shijiazhuang 050061, China \\ ${ }^{2}$ Hebei Academy of Forestry and Grassland Investigation and Planning, Shijiazhuang 050051, China
}

Received: 13 December 2020

Accepted: 25 January 2021

\begin{abstract}
Green roofs are a new measure to control city nonpoint source pollution. The objective of this study was to examine the effects of substrate depth and biochar on the capacity of green roofs to intercept rainfall and reduce pollution in runoff. The amount and water quality of rainfall and the runoff from asphalt roofs (AR) and green roofs with or without biochar substrate were measured for 93 rainfall events. The substrate depth significantly increased the green roof runoff retention rate, while it did not significantly affect the concentration of water quality parameters in the runoff. The addition of biochar to the substrate could increase the retention rate of green roof runoff and could significantly reduce the electrical conductivity (EC) and concentrations of $\mathrm{TN}, \mathrm{NO}_{3}^{-}-\mathrm{N}, \mathrm{NH}_{4}^{+}-\mathrm{N}, \mathrm{COD}, \mathrm{TOC}, \mathrm{K}^{+}, \mathrm{Ca}^{2+}, \mathrm{Cl}^{-}$, $\mathrm{SO}_{4}{ }^{2-}, \mathrm{Fe}$ and $\mathrm{Zn}$ in the green roof runoff, however, biochar increased the concentration of TIC in the runoff. Notably, the addition of biochar to the green roof substrate prominently reduced the pollution load of TN, $\mathrm{COD}$, and $\mathrm{NO}_{3}^{-}-\mathrm{N}$ in the runoff and therefore it was as a sink. The main pollution sources of green roof without biochar substrate were organic, ion, nutrient, physicochemical, and metal pollution. However, from the green roofs with biochar substrate, the pollution sources were severely affected by biochar and mainly were organic and metal, ion, nutrient pollution, and biochar. These results provide a scientific basis for the design and application of green roofs to manage and control urban storm runoff.
\end{abstract}

Keywords: green roof, substrate components, nonpoint source pollution, runoff retention, pollution source

*e-mail: z_qqian@163.com 


\section{Introduction}

Green roofs (also known as vegetation roofs and ecological roofs) are a special type of surface cover in urban areas and are a new measure to control urban nonpoint source pollution. Compared to other controlling measures (such as biological detention pond, constructed wetland, riparian buffer zone, etc.), green roof has the advantages of saving land resources, low cost and increasing urban greening rate. Nowadays, green roof have been widely used in developed countries such as the United States, Sweden, Singapore, and France [14]. Previous studies have shown that green roofs have multiple eco-environmental benefits, such as reducing the urban heat island effect $[5,6]$, reducing storm runoff and the risk of urban waterlogging [7], reducing noise pollution [8], improving air quality [9], and providing wildlife habitats and increasing biodiversity [10].

The green roof system has some capacity to regulate the hydrological process of storm runoff and to reduce the risk of urban flooding [11]. Previous studies found that green roofs can effectively reduce the flow of storm runoff [12, 13]. Zhang et al. [7] found that the average runoff retention ratio of green roofs reached $77.2 \%$, and the average annual retention of rainfall volume was as high as $758.7 \mathrm{~mm}$. Cipolla et al. [14] that the proportion of runoff retention of green roofs ranged from 6.4 to $100 \%$ and that the average annual retention runoff rate reached $51.9 \%$ [14]. In addition, green roof substrates and plants can absorb part of the rainwater, so green roofs can delay the runoff generation time and reduce the flood peak flow [15].

The retention runoff capacity of green roofs is conditioned by a variety of factors, primarily including the thickness of the green roof substrate, plant species, roof slope, roof age, and weather characteristics (such as dry period length, rainfall intensity, rainfall duration, temperature, and humidity) [16]. The thickness of the substrate layer is an important factor affecting the ability of green roofs to retain runoff [7]. The thicker the substrate layer is, the greater the saturation capacity and the better the interception effect on rainfall. Nardini and Crasso [17] found that a $12 \mathrm{~cm}$ thick substrate reduces runoff by $63 \%$, whereas a $20 \mathrm{~cm}$ thick matrix reduces runoff by $83 \%$. Plants can also increase the retention capacity of green roofs. Harper et al. [18] conducted a comparative experiment in Missouri, USA, and found that plants significantly reduced runoff from green roofs; the green roofs without plants reduced the roof runoff by $40 \%$, whereas those with plants reduced runoff by $60 \%$. An increase in the slope of a roof may result in a decrease in the runoff retention rate. Getter et al. [19] found that the runoff retention capacity of green roofs decreased significantly with the increase in roof slope. However, Beecham and Razzaghmanesh [20] showed that the slope did not significantly affect the runoff retention capacity of green roofs. Rainfall characteristics are also important factors affecting the rainfall runoff retention capacity of a green roof. An antecedent dry weather period is an important factor in determining the retention effect of green roof on storm runoff. The longer the dry period is, the more sufficient the runoff capacity of a green roof will recover [7]. Rainfall volume is also a decisive factor, and the roof has a specific water retention capacity which is independent of the amount of rainfall [21].

While regulating the hydrological process of storm runoff, the green roof also has a serious impact on the release law of pollutants and pollution load in rainfall runoff. Green roofs can decrease the concentrations of pollutants in runoff by absorption, transformation, and filtration, but pollutants can also be released from the substrate layer into runoff. In recent years, the impact of green roofs on the quality of rainstorm runoff has become a hot topic of research [22, 23], but studies have produced somewhat different results. In one study, green roofs neutralized the $\mathrm{pH}$ of rainstorm runoff [24]. Vijayaraghavan et al. [4] found that green roofs release large amounts of N, P, and TOC and increase the EC and the contents of salt, $\mathrm{Fe}, \mathrm{Cu}$, and $\mathrm{Al}$ in runoff, as a potential source of pollution. However, Seidl et al. [25] found that green roofs reduce the concentration of $\mathrm{N}$ in runoff, acting as a trap for nutrients. Todorov et al. [3] found that green roofs reduced the concentrations of $\mathrm{N}$, $\mathrm{TP}$, and $\mathrm{Cl}^{-}$in runoff but was a source of contamination by increasing the concentrations of $\mathrm{PO}_{4}^{3-}$, $\mathrm{DIC}$, and DOC. Recently, the focus of research has been on improving the water quality of green roof runoff by the addition of repairing materials into roof substrate (such as biochar) [26, 27]. Qiu [28] found that application of stabilized sludge (from wastewater treatment plants) to extensive green roofs can reduce the concentration of nutrients in runoff. However, this research area remains in the initial stage, and the adsorption capacity of biochar for pollutants in green roof runoff has not been studied in detail.

Based on the above question, this study primarily focuses on the influence of green roofs on rainfall runoff quality and quantity and identifying the pollution sources. The main aims are as following: 1) to reveal differences between substrate depth and biochar addition on pollutant release processes, runoff water quality, and pollution loads in runoff; 2) to analyze the effects of substrate depth and biochar addition on the runoff retention capacity of green roofs; 3) to identify the main pollution sources affecting the water quality of green roof runoff. Thus, the results from this study will be useful in clarifying the effects of green roofs in controlling urban storm runoff and in designing scientifically sound green roofs.

\section{Materials and Methods}

\section{Study Site}

The experimental site was located on the rooftop of an office building in Shijiazhuang City, Hebei 


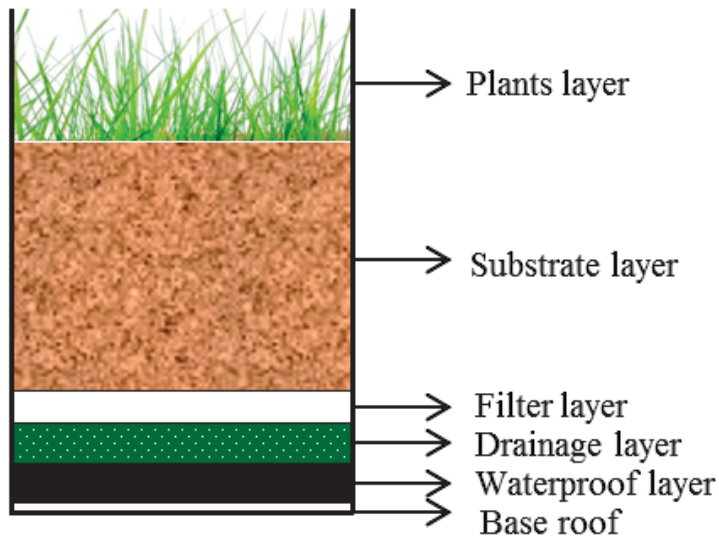

Fig. 1. The structure diagram of green roof.

Province, China. Roadways and land under construction surrounded the rooftop on all sides. There are no large buildings around the site (stronger insolation and wind), which is beneficial to the green roof to quickly recover the runoff retention capacity. A semi-humid, semi-arid continental monsoonal climate characterizes the region. The mean annual temperature is between 13.3 and $15.0^{\circ} \mathrm{C}$, and the mean annual precipitation of 400-750 mm [29]. Most precipitation occurs between June and September (Supplementary Fig. 1), with the highest temperatures recorded between July and September.

\section{Experimental Design}

Eighteen pilot-scale extensive green roofs $(1.0 \mathrm{~m}$ length $\times 1.0 \mathrm{~m}$ width) and two control (asphalt) roofs
(ARs) $(1.0 \mathrm{~m}$ length $\times 1.0 \mathrm{~m}$ width) were constructed in April 2016 on the roof of an office building. The material of the pilot-scale green roofs and the ARs was stainless steel and there was a $40 \mathrm{~cm}$ fence to prevent rainwater splash from the green roof.

The green roof assembly consisted of five layers (Fig. 1), including plants layer, substrate layer, filter layer (nonwoven geotextile), drainage layer, and waterproof layer (it is modified asphalt felt paved onto the original stainless steel roof). A water outlet was constructed on the bottom of the stainless steel roof.

The extensive green roofs included four types with different substrate thickness. The substrate thickness was $5,10,15$, or $20 \mathrm{~cm}$; the thickness was $10 \mathrm{~cm}$ for six green roofs, and for the other twelve green roofs, the thickness was $5 \mathrm{~cm}$ for four, $15 \mathrm{~cm}$ for four, and $20 \mathrm{~cm}$ for four. Two types of substrates were used as a component of the green roofs. The components of the first type of substrate were peat, vermiculite, perlite, biochar (coconut shell biochar), and sawdust allocated at the ratio 2:3:3:1:0.5, respectively. The components of the second type of substrate were peat, vermiculite, perlite, and sawdust, and the volume ratio of the matrix was 2:3:3:0.5, respectively. The physicochemical properties of these substrate components are outlined in Supplementary Table 1. Physicochemical properties of coconut shell biochar are shown in Supplementary Table 2. Two green roofs with substrate thickness of $5,10,15$, or $20 \mathrm{~cm}$ were filled with the first substrate with biochar (GRb5-1, GRb5-2, GRb10-1, GRb10-2, GRb15-1, GRb15-2, GRb20-1, GRb20-2) and planting vegetation, and two green roof for each thickness was filled with the second substrate without biochar (GR5-3, GR5-4, GR10-3, GR10-4, GR15-3, GR15-4,

Table 1. The rainfall runoff retention rate and retention amount of green roofs and asphalt roofs.

\begin{tabular}{|c|c|c|c|c|c|c|}
\hline \multirow{2}{*}{ Roof } & \multicolumn{3}{|c|}{ Runoff retention rate (\%) } & \multicolumn{3}{c|}{ Runoff retention volumn (mm) } \\
\cline { 2 - 7 } & 2016 & 2017 & Sum & 2016 & 2017 & Sum \\
\hline GRb5 & 40.53 & 55.56 & $47.7 \mathrm{~b}$ & 235.89 & 295.13 & 531.02 \\
\hline GR5 & 39.23 & 55.72 & $47.10 \mathrm{~b}$ & 228.31 & 296.01 & 524.32 \\
\hline GRb10 & 44.91 & 63.96 & $53.99 \mathrm{bd}$ & 261.35 & 339.77 & 601.12 \\
\hline GR10 & 43.91 & 62.34 & $52.71 \mathrm{bd}$ & 255.58 & 331.16 & 586.74 \\
\hline GRn10 & 39.56 & 58.26 & $48.48 \mathrm{~b}$ & 230.25 & 309.48 & 539.73 \\
\hline GRb15 & 51.91 & 69.74 & $60.42 \mathrm{~cd}$ & 302.10 & 370.45 & 672.55 \\
\hline GR15 & 49.42 & 65.29 & $56.99 \mathrm{bd}$ & 287.62 & 346.82 & 634.44 \\
\hline GRb20 & 58.54 & 75.23 & $66.5 \mathrm{c}$ & 340.69 & 399.61 & 740.30 \\
\hline GR20 & 53.85 & 72.27 & $62.64 \mathrm{~cd}$ & 313.42 & 383.92 & 697.34 \\
\hline AR & 3.04 & 2.40 & $2.74 \mathrm{a}$ & 17.70 & 12.75 & 30.45 \\
\hline
\end{tabular}

Note: GRb5, GRb10, GRb15 and GRb20 = Green roof with substrate (green roof were filled with the first substrate with biochar) thickness of 5, 10, 15, or $20 \mathrm{~cm}$, respectively; GR5, GR10, GR15 and GR20 = Green roof with substrate (green roof were filled with the second substrate without biochar) thickness of 5, 10, 15, or $20 \mathrm{~cm}$, respectively; GRn10= green roof with a $10 \mathrm{~cm}$ thick substrate was filled with the second substrate type and without plants; AR = asphalt roof; The values followed by different letter for roof designate significantly different at $P<0.05$ level by One-way ANOVA(post-hoc). 
Table 2. Correlation coefficients between the rainfall characteristics and the runoff retention capacity of green roofs.

\begin{tabular}{|c|c|c|c|c|c|c|c|c|c|}
\hline Parameters & GRb5 & GR5 & GRb10 & GR10 & GRn10 & GRb15 & GR15 & GRb20 & GR20 \\
\hline RV & -0.375 & -0.268 & -0.382 & -0.287 & -0.190 & $-0.476^{*}$ & -0.380 & $-0.504 *$ & -0.399 \\
\hline RD & $-0.536 * *$ & $-0.550^{* *}$ & $-0.559 * *$ & $-0.561 * *$ & $-0.451 *$ & $-0.631 * *$ & $-0.647 * *$ & $-0.681 * *$ & $-0.673 * *$ \\
\hline ADWP & 0.316 & 0.364 & 0.141 & 0.350 & $0.458^{*}$ & 0.081 & 0.246 & 0.092 & 0.225 \\
\hline MRI & -0.019 & 0.112 & 0.036 & 0.084 & 0.080 & -0.082 & -0.035 & -0.016 & 0.045 \\
\hline
\end{tabular}

Note: $* P<0.05$; ${ }^{*} P<0.01$; GRb5, GRb10, GRb15 and GRb20 = Green roof with substrate(green roof were filled with the first substrate with biochar) thickness of 5, 10, 15, or $20 \mathrm{~cm}$, respectively; GR5, GR10, GR15 and GR20 = Green roof with substrate(green roof were filled with the second substrate without biochar) thickness of 5, 10, 15, or $20 \mathrm{~cm}$, respectively; GRn10 = green roof with a $10 \mathrm{~cm}$ thick substrate was filled with the second substrate type and without plants; $\mathrm{AR}=$ asphalt roof; $\mathrm{RV}=\mathrm{Rain}$ volume; $\mathrm{RD}=\mathrm{Rain}$ duration; ADWP = Antecedent dry weather period; MRI = Maximum rainfall intensity.

GR20-3, GR20-4) and planting vegetation. Furthermore, two green roof with a $10 \mathrm{~cm}$ thick substrate was filled with the second substrate type and without plants (GR10-5 and GR10-6).

Buddhanail (Sedum lineare Thunb) was selected as the green roof plants for this study due to its ability survive in extreme climatic conditions. The planting density is $100 \mathrm{strain} / \mathrm{m}^{2}$ (plant spacing is $10 \mathrm{~cm}$ and line spacing 8-10 cm).

\section{Sampling and Analyses}

\section{Roof Runoff and Rainfall Volume Measurement}

Before sampling, mix the water samples evenly, measure the volume of rainfall and roof runoff samples with the measuring cylinder and reserve $1 \mathrm{~L}$ water sample for testing.

\section{Roof Runoff and Rainfall Sampling}

Samplings of roof runoff and rainfall were carried out from May 2016 to November 2017, and were collected by using a polyethylene runoff sampler (the volume is 80 liters). Three water samples were collected from each roof and rainfall sampler within $1 \mathrm{~h}$ after each rainfall and were stored in $1.5 \mathrm{~L}$ polyethylene bottles. During the study, 93 rainfall events were monitored, and 25 green roof runoff samples were collected. Rainfall characteristics for the rain events are shown in Supplementary Table 3.

\section{Physical-Chemical Analyses}

After collection, the samples were immediately prepared for analyses. The samples of green roof runoff, control roof runoff, and rainfall were analyzed for 16 water quality parameters. The monitored runoff parameters included $\mathrm{pH}$, electrical conductivity [EC], total nitrogen [TN], ammonium nitrogen $\left[\mathrm{NH}_{4}^{+}-\mathrm{N}\right]$, nitrate nitrogen $\left[\mathrm{NO}_{3}{ }^{-} \mathrm{N}\right]$, total phosphorus [TP], Chemical oxygen demand [COD], total suspended solids [TSS], total organic carbon [TOC], total inorganic carbon [TIC], chloride $\left[\mathrm{Cl}^{-}\right]$, sulphate $\left[\mathrm{SO}_{4}^{2-}\right]$, potassium $\left[\mathrm{K}^{+}\right]$, calcium $\left[\mathrm{Ca}^{2+}\right], \mathrm{Fe}$, and $\mathrm{Zn}$. The $\mathrm{pH}$ and EC were analyzed using a portable meter (HQ40D, Hach, USA).

Table 3. Comparison of the pollutants load for green roof for green roof, asphalt roof and rainwater.

\begin{tabular}{|c|c|c|c|c|c|c|c|}
\hline Parameters & $\mathrm{TN}\left(\mathrm{g} / \mathrm{m}^{2}\right)$ & $\mathrm{COD}\left(\mathrm{g} / \mathrm{m}^{2}\right)$ & $\mathrm{TP}\left(\mathrm{g} / \mathrm{m}^{2}\right)$ & $\mathrm{NH}_{4}^{+}-\mathrm{N}\left(\mathrm{g} / \mathrm{m}^{2}\right)$ & $\mathrm{NO}_{3}^{-}-\mathrm{N}\left(\mathrm{g} / \mathrm{m}^{2}\right)$ & $\mathrm{TSS}\left(\mathrm{g} / \mathrm{m}^{2}\right)$ & $\mathrm{TIC}\left(\mathrm{g} / \mathrm{m}^{2}\right)$ \\
\hline GRb5 & $0.114 \pm 0.166^{\mathrm{ac}}$ & $1.561 \pm 1.802^{\mathrm{ac}}$ & $0.005 \pm 0.009^{\mathrm{ab}}$ & $0.024 \pm 0.040^{\mathrm{b}}$ & $0.048 \pm 0.066^{\mathrm{a}}$ & $0.375 \pm 0.887^{\mathrm{a}}$ & $0.062 \pm 0.078^{\mathrm{a}}$ \\
\hline GR5 & $0.277 \pm 0.359^{\mathrm{ab}}$ & $2.469 \pm 3.459^{\mathrm{ad}}$ & $0.003 \pm 0.009^{\mathrm{ab}}$ & $0.030 \pm 0.048^{\mathrm{b}}$ & $0.199 \pm 0.300^{\mathrm{b}}$ & $0.390 \pm 0.930^{\mathrm{a}}$ & $0.087 \pm 0.167^{\mathrm{a}}$ \\
\hline GRb10 & $0.087 \pm 0.110^{\mathrm{c}}$ & $1.541 \pm 1.549^{\mathrm{ac}}$ & $0.004 \pm 0.009^{\mathrm{ab}}$ & $0.020 \pm 0.038^{\mathrm{b}}$ & $0.028 \pm 0.039^{\mathrm{a}}$ & $0.305 \pm 0.562^{\mathrm{a}}$ & $0.044 \pm 0.075^{\mathrm{a}}$ \\
\hline GR10 & $0.370 \pm 0.437^{\mathrm{bd}}$ & $2.106 \pm 2.778^{\mathrm{ad}}$ & $0.002 \pm 0.003^{\mathrm{ab}}$ & $0.027 \pm 0.044^{\mathrm{b}}$ & $0.280 \pm 0.326^{\mathrm{b}}$ & $0.434 \pm 0.869^{\mathrm{a}}$ & $0.036 \pm 0.096^{\mathrm{a}}$ \\
\hline GRn10 & $0.359 \pm 0.400^{\mathrm{be}}$ & $1.569 \pm 1.655^{\mathrm{ac}}$ & $0.003 \pm 0.005^{\mathrm{ab}}$ & $0.033 \pm 0.054^{\mathrm{b}}$ & $0.325 \pm 0.387^{\mathrm{b}}$ & $0.489 \pm 0.922^{\mathrm{a}}$ & $0.034 \pm 0.084^{\mathrm{a}}$ \\
\hline GRb15 & $0.169 \pm 0.262^{\mathrm{ace}}$ & $2.603 \pm 3.896^{\mathrm{ab}}$ & $0.007 \pm 0.015^{\mathrm{b}}$ & $0.033 \pm 0.065^{\mathrm{b}}$ & $0.062 \pm 0.095^{\mathrm{a}}$ & $0.516 \pm 1.019^{\mathrm{ab}}$ & $0.032 \pm 0.036^{\mathrm{a}}$ \\
\hline GR15 & $0.375 \pm 0.468^{\mathrm{bd}}$ & $4.492 \pm 6.174^{\mathrm{b}}$ & $0.004 \pm 0.008^{\mathrm{ab}}$ & $0.046 \pm 0.072^{\mathrm{bc}}$ & $0.333 \pm 0.350^{\mathrm{b}}$ & $0.414 \pm 0.550^{\mathrm{a}}$ & $0.044 \pm 0.114^{\mathrm{a}}$ \\
\hline GRb20 & $0.171 \pm 0.229^{\mathrm{acde}}$ & $1.639 \pm 1.993^{\mathrm{acd}}$ & $0.006 \pm 0.008^{\mathrm{ab}}$ & $0.028 \pm 0.048^{\mathrm{b}}$ & $0.082 \pm 0.101^{\mathrm{a}}$ & $0.399 \pm 0.832^{\mathrm{a}}$ & $0.029 \pm 0.023^{\mathrm{a}}$ \\
\hline GR20 & $0.310 \pm 0.433^{\mathrm{ade}}$ & $3.54 \pm 5.071^{\mathrm{bd}}$ & $0.005 \pm 0.008^{\mathrm{ab}}$ & $0.048 \pm 0.068^{\mathrm{bc}}$ & $0.197 \pm 0.210^{\mathrm{b}}$ & $0.407 \pm 0.681^{\mathrm{a}}$ & $0.062 \pm 0.127^{\mathrm{a}}$ \\
\hline AR & $0.135 \pm 0.119^{\mathrm{ac}}$ & $1.399 \pm 1.094^{\mathrm{ac}}$ & $0.005 \pm 0.016^{\mathrm{ab}}$ & $0.094 \pm 0.082^{\mathrm{a}}$ & $0.023 \pm 0.026^{\mathrm{a}}$ & $1.096 \pm 2.209^{\mathrm{b}}$ & $0.050 \pm 0.029^{\mathrm{a}}$ \\
\hline Rain & $0.115 \pm 0.080^{\mathrm{ac}}$ & $0.628 \pm 0.523^{\mathrm{c}}$ & $0.001 \pm 0.001^{\mathrm{a}}$ & $0.079 \pm 0.057^{\mathrm{ac}}$ & $0.027 \pm 0.023^{\mathrm{a}}$ & $0.360 \pm 0.413^{\mathrm{a}}$ & $0.042 \pm 0.031^{\mathrm{a}}$ \\
\hline
\end{tabular}


Table 3. Continued.

\begin{tabular}{|c|c|c|c|c|c|c|c|}
\hline Parameters & TOC $\left(\mathrm{g} / \mathrm{m}^{2}\right)$ & $\mathrm{K}^{+}\left(\mathrm{g} / \mathrm{m}^{2}\right)$ & $\mathrm{Ca}^{2+}\left(\mathrm{g} / \mathrm{m}^{2}\right)$ & $\mathrm{Fe}\left(\mathrm{mg} / \mathrm{m}^{2}\right)$ & $\mathrm{Zn}\left(\mathrm{mg} / \mathrm{m}^{2}\right)$ & $\mathrm{Cl}^{-}\left(\mathrm{g} / \mathrm{m}^{2}\right)$ & $\mathrm{SO}_{4}^{2-}\left(\mathrm{g} / \mathrm{m}^{2}\right)$ \\
\hline GRb5 & $0.475 \pm 0.658^{\mathrm{ac}}$ & $0.033 \pm 0.034^{\mathrm{a}}$ & $0.479 \pm 0.497^{\mathrm{ab}}$ & $0.715 \pm 1.053^{\mathrm{a}}$ & $0.145 \pm 0.135^{\mathrm{b}}$ & $0.170 \pm 0.215^{\mathrm{a}}$ & $0.635 \pm 0.845^{\mathrm{a}}$ \\
\hline GR5 & $0.656 \pm 0.729^{\mathrm{bc}}$ & $0.046 \pm 0.045^{\mathrm{a}}$ & $0.842 \pm 0.864^{\mathrm{b}}$ & $0.792 \pm 0.948^{\mathrm{a}}$ & $0.305 \pm 0.334^{\mathrm{bc}}$ & $0.217 \pm 0.259^{\mathrm{ab}}$ & $0.829 \pm 0.948^{\mathrm{a}}$ \\
\hline GRb10 & $0.543 \pm 0.731^{\mathrm{ac}}$ & $0.039 \pm 0.046^{\mathrm{a}}$ & $0.432 \pm 0.506 \mathrm{a}^{\mathrm{b}}$ & $0.915 \pm 1.643^{\mathrm{ab}}$ & $0.101 \pm 0.116^{\mathrm{b}}$ & $0.135 \pm 0.151^{\mathrm{a}}$ & $0.766 \pm 1.355^{\mathrm{a}}$ \\
\hline GR10 & $0.644 \pm 0.820^{\mathrm{bc}}$ & $0.064 \pm 0.079^{\mathrm{a}}$ & $0.898 \pm 1.117^{\mathrm{b}}$ & $1.241 \pm 2.192^{\mathrm{ab}}$ & $0.231 \pm 0.241^{\mathrm{b}}$ & $0.195 \pm 0.252^{\mathrm{ab}}$ & $0.841 \pm 1.103^{\mathrm{a}}$ \\
\hline GRn10 & $0.551 \pm 0.774^{\mathrm{ac}}$ & $0.053 \pm 0.060^{\mathrm{a}}$ & $0.899 \pm 1.018^{\mathrm{b}}$ & $1.376 \pm 1.952^{\mathrm{ab}}$ & $0.350 \pm 0.312^{\mathrm{b}}$ & $0.143 \pm 0.169^{\mathrm{a}}$ & $0.745 \pm 0.901^{\mathrm{a}}$ \\
\hline GRb15 & $0.573 \pm 0.735^{\mathrm{ac}}$ & $0.083 \pm 0.087^{\mathrm{ad}}$ & $0.448 \pm 0.459^{\mathrm{ab}}$ & $1.644 \pm 2.774^{\mathrm{ab}}$ & $0.231 \pm 0.225^{\mathrm{b}}$ & $0.153 \pm 0.147^{\mathrm{a}}$ & $0.927 \pm 0.998^{\mathrm{a}}$ \\
\hline GR15 & $0.636 \pm 0.675^{\mathrm{bc}}$ & $0.135 \pm 0.143^{\mathrm{bd}}$ & $0.958 \pm 0.962^{\mathrm{b}}$ & $2.365 \pm 2.889^{\mathrm{b}}$ & $0.594 \pm 0.604^{\mathrm{c}}$ & $0.238 \pm 0.217^{\mathrm{ab}}$ & $0.953 \pm 0.980^{\mathrm{a}}$ \\
\hline GRb20 & $0.371 \pm 0.396^{\mathrm{ac}}$ & $0.064 \pm 0.066^{\mathrm{a}}$ & $0.487 \pm 0.489^{\mathrm{ab}}$ & $1.324 \pm 2.033^{\mathrm{ab}}$ & $0.191 \pm 0.171^{\mathrm{b}}$ & $0.148 \pm 0.135^{\mathrm{a}}$ & $0.735 \pm 0.659^{\mathrm{a}}$ \\
\hline GR20 & $0.760 \pm 0.851^{\mathrm{bc}}$ & $0.177 \pm 0.163^{\mathrm{b}}$ & $0.696 \pm 0.600^{\mathrm{b}}$ & $2.388 \pm 3.135^{\mathrm{b}}$ & $0.439 \pm 0.497^{\mathrm{b}}$ & $0.350 \pm 0.371^{\mathrm{b}}$ & $1.121 \pm 1.312^{\mathrm{a}}$ \\
\hline AR & $0.256 \pm 0.168^{\mathrm{ac}}$ & $0.003 \pm 0.003^{\mathrm{c}}$ & $0.156 \pm 0.144^{\mathrm{a}}$ & $0.561 \pm 0.557^{\mathrm{a}}$ & $1.415 \pm 0.982^{\mathrm{a}}$ & $0.021 \pm 0.028^{\mathrm{c}}$ & $0.177 \pm 0.148^{\mathrm{b}}$ \\
\hline Rain & $0.106 \pm 0.122^{\mathrm{a}}$ & $0.004 \pm 0.003^{\mathrm{c}}$ & $0.091 \pm 0.132^{\mathrm{a}}$ & $0.256 \pm 0.289^{\mathrm{a}}$ & $1.525 \pm 0.983^{\mathrm{a}}$ & $0.014 \pm 0.029^{\mathrm{c}}$ & $0.190 \pm 0.171^{\mathrm{b}}$ \\
\hline
\end{tabular}

Note: GRb5, GRb10, GRb15 and GRb20 = Green roof with substrate(green roof were filled with the first substrate with biochar) thickness of 5, 10, 15, or $20 \mathrm{~cm}$, respectively; GR5, GR10, GR15 and GR20 = Green roof with substrate(green roof were filled with the second substrate without biochar) thickness of 5,10,15, or $20 \mathrm{~cm}$, respectively; GRn10= green roof with a $10 \mathrm{~cm}$ thick substrate was filled with the second substrate type and without plants; $\mathrm{AR}=$ asphalt roof;

The values followed by different letter for roof designate significantly different at $P<0.05$ level by One-way ANOVA(post-hoc).

The other water quality indicators were measured strictly in accordance with the guidelines formulated by SEPAC (2002a) [30].

\section{Data Analysis}

One-way ANOVA (post-hoc) was performed to compare significant differences in runoff water quality and quantity among the green roofs, control roofs and rainfall. Correlation analysis (CA) was used to determine the degree of dependence between runoff retention capacity of green roofs and rainfall characteristics. Principal component analysis (PCA) was performed to identify the primary pollution sources of green roof runoff. In this study, PCA was used to reduce the original sixteen variables into five and four independent factors for the nonbiochar and biochar substrates, respectively. The Kaiser-Meyer-Olkin and Bartlett's sphericity test were 0.712 and 740.5 $(P<0.05)$, and 0.799 and $783.9 \quad(P<0.05)$ for the nonbiochar and biochar substrates, respectively, which indicating that PCA was trustworthy for extracting information from variables. On the basis of Eigenvalues $>1$, PCA generated five and four principal components (PCs), which explained 81.06 and $77.16 \%$ of the total variance for the non-biochar and biochar substrates, respectively. When the absolute loading values were $>0.75, \quad 0.75-0.50$, and $0.50-0.30$, the factor loading were defined as "strong", "moderate", and "weak", respectively [31].

All statistical analyses were performed using the SPSS 21 statistical software package (SPSS Inc., USA) and R v 3.5.3 (R Core Team, 2019).

\section{Results}

\section{Effect of Green Roof on Runoff Retention}

\section{Effect of Green Roofs with Different Substrate Depths on Runoff Retention}

The rainfall runoff retention rate and retention amount of the green roofs and ARs are shown in Table 1. The retention rates for green roofs and ARs ranged from $1.37-100 \%$ and from $0-52.78 \%$, respectively. As shown in Table 1, with the increase in substrate thickness, the green roof runoff retention rate increased gradually: GRm5 $(47.35 \%)<\mathrm{GRm} 10 \quad(53.78 \%)<\mathrm{GRm} 15$ $(59.09 \%)<$ GRm20 (64.97\%)(GRm5, GRm10, GRm15, GRm20 were the mean value of the runoff retention for all substrate of the $5 \mathrm{~cm}, 10 \mathrm{~cm}, 15 \mathrm{~cm}$ and $20 \mathrm{~cm}$, respectively). The runoff retention rate of the green roofs was significantly higher than that of ARs. The runoff retention rate of GRb15, GRb20, and GR20 was significantly higher than that of GRb5, GR5, and GRn10, whereas the retention rate of GRb20 was significantly higher than that of the GRb10, GR10, and GR15 roof.

\section{Effect of Green Roofs with Different Substrate Components on Runoff Retention}

The runoff retention rate was not significantly different between the substrates with and without biochar, although the addition of biochar in the substrate increased the retention rate of green roof runoff. As shown in Table 1, the comparisons of runoff retention 


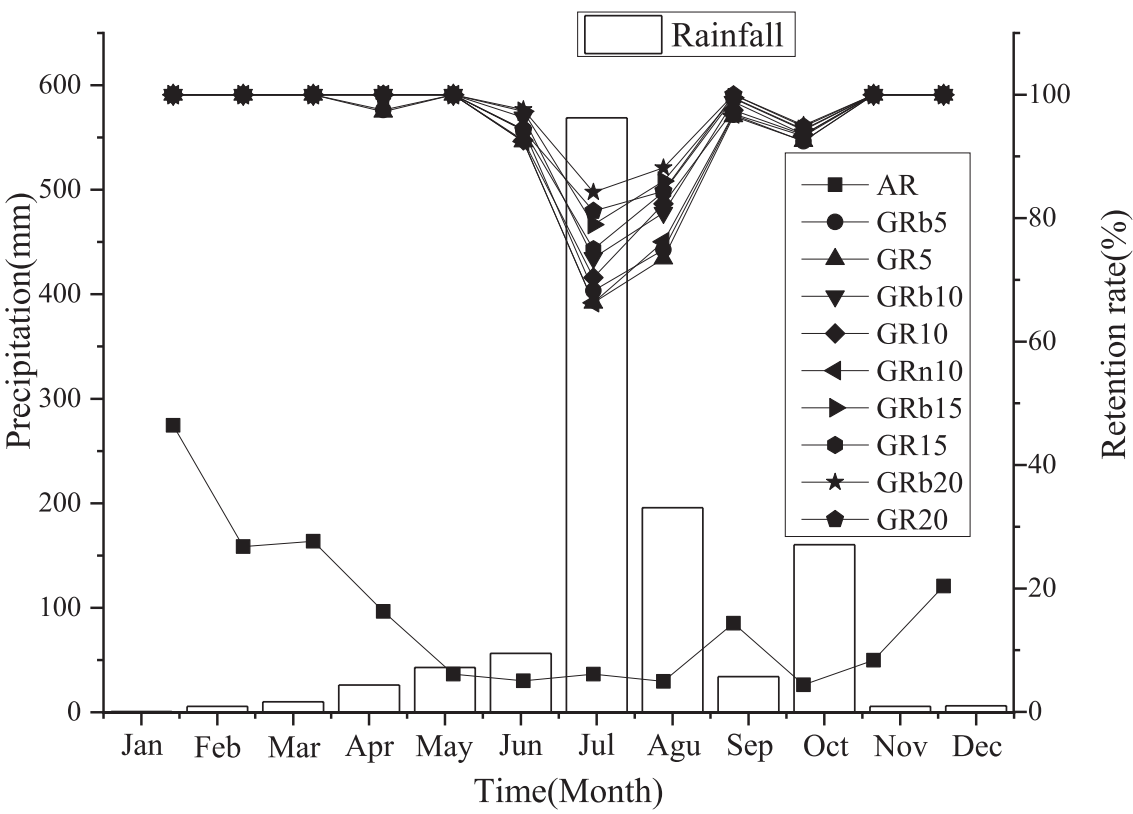

Fig. 2. The monthly variation of rainfall, and green roof retention rate from May 2016 to November 2017.

Note: GRb5, GRb10, GRb15 and GRb20 = Green roof with substrate (green roof were filled with the first substrate with biochar) thickness of 5, 10, 15, or $20 \mathrm{~cm}$, respectively; GR5, GR10, GR15 and GR20 = Green roof with substrate (green roof were filled with the second substrate without biochar) thickness of 5,10,15, or $20 \mathrm{~cm}$, respectively; GRn10 = green roof with a $10 \mathrm{~cm}$ thick substrate was filled with the second substrate type and without plants; $\mathrm{AR}=$ asphalt roof.

rates of roofs with different substrate components were as follow: GRb5 (47.70\%)>GR5 (47.10\%), GRb10 $(53.99 \%)>$ GR10 $\quad(52.71 \%), \quad$ GRb15 $\quad(60.42 \%)>$ GR 15 (56.99\%), and GRb20 (66.50\%)>GR20 (62.64\%).

\section{Effect of Green Roofs with or Without Plants on Runoff Retention}

Taking green roofs with substrate thickness of $10 \mathrm{~cm}$ as examples, the effects of plants on the green roof runoff retention rate were determined (Table 1). The green roofs with plants (GRb10 and GR10) and the green roof (GRn10) without plants did not show significant differences in the runoff retention. However, the retention of GRb10 (53.99\%) and GR10 (52.71\%) was greater than that of GRn10 (48.41\%), indicating that plants could increase the runoff retention rate of green roof.

\section{Effect of Rainfall Characteristics on the Runoff Retention Capacity of Green Roofs}

Correlation analyses results showed a negative correlation between the rainfall volume, rainfall duration and runoff retention capacity of green roofs (Table 2). There was a positive correlation between the length of the ADWP (antecedent dry weather period) and the runoff retention capacity of green roofs. However, the maximum rainfall intensity did not markedly affect the runoff retention capacity of green roofs.

\section{Monthly Runoff Retention of Green Roofs}

From Fig. 2, the monthly variation in the green roof runoff retention rate with different substrate thicknesses was consistent. The lowest green roof runoff retention rate was in the month with the largest rainfall volume, indicating that the monthly variation in runoff retention rate of green roofs was primarily affected by rainfall amount.

\section{Quality of Green Roof Runoff Water}

$$
p H, E C \text {, and TSS }
$$

The mean pH values in GRb5 (7.19), GRb10 (7.13), GRb15 (7.13), GRb20 (7.23), and AR (7.21) runoff were significantly higher than that of rainfall (6.95) (Fig. 3a). The $\mathrm{pH}$ in the runoff of green roofs with biochar addition was higher than that of green roofs without biochar, indicating that the addition of biochar increased the $\mathrm{pH}$ of the runoff. However, the green roofs with biochar addition to the substrate showed no significant differences in the runoff $\mathrm{pH}$ for any substrate thickness (Fig. 3a). Thus, the substrate thickness had no significant effect on the $\mathrm{pH}$ of the green roof runoff. In addition, the runoff $\mathrm{pH}$ among GRb10, GR10 and GRn10 (7.00) has no significant difference, indicating that the growth of plants did not affect the $\mathrm{pH}$ of green roof runoff.

The EC in all green roof runoff was significantly higher than that in rainwater and in runoff from ARs (Fig. 3b), demonstrating that many ions were released 
a)

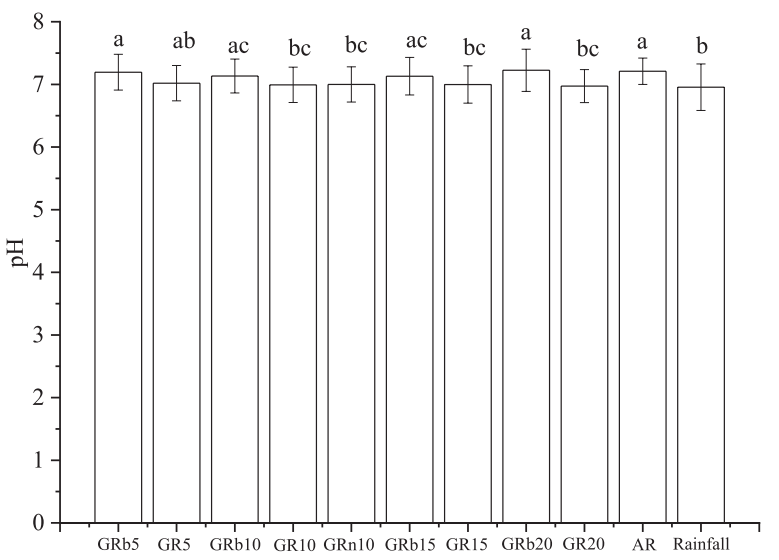

b)

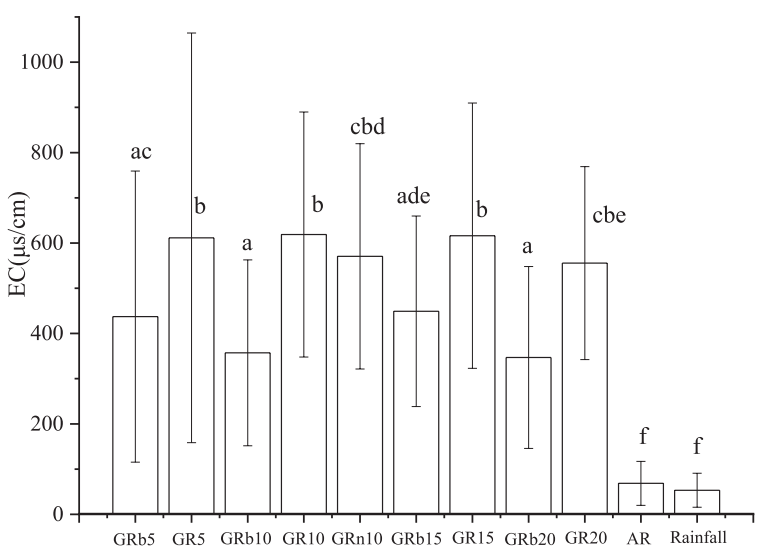

c)

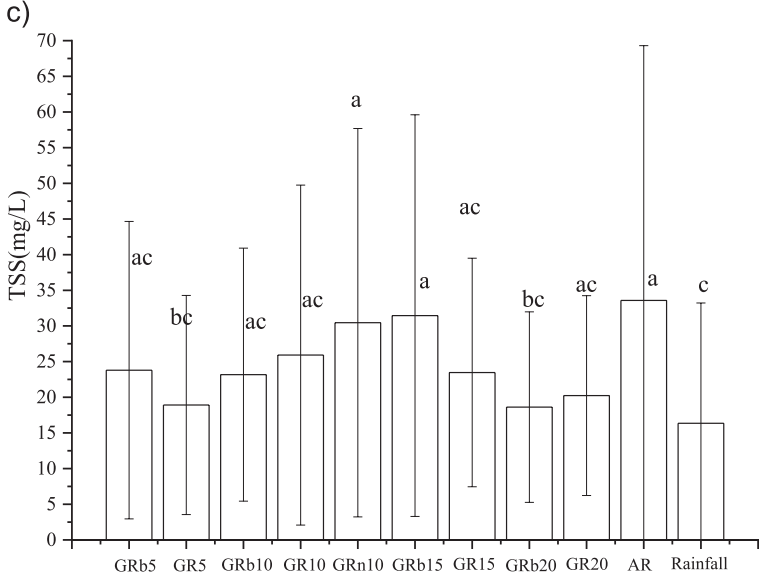

Fig. 3. The average $\mathrm{pH}, \mathrm{EC}$ and TSS concentrations of monitoring rainfall events from the green roof, asphalt roof, and rainfall.

Note: GRb5, GRb10, GRb15 and GRb20 = Green roof with substrate (green roof were filled with the first substrate with biochar) thickness of 5, 10, 15, or $20 \mathrm{~cm}$, respectively; GR5, GR10, GR15 and GR20 = Green roof with substrate (green roof were filled with the second substrate without biochar) thickness of $5,10,15$, or $20 \mathrm{~cm}$, respectively; GRn10 = green roof with a $10 \mathrm{~cm}$ thick substrate was filled with the second substrate type and without plants; $\mathrm{AR}=$ asphalt roof.

The values refer to means \pm S.D. The values followed by different letter for green roof, asphalt roof and rainfall designate significantly different at $P<0.05$ level by One-way ANOVA (post-hoc).

from the green roof substrate, as the source of EC contamination. Similar to $\mathrm{pH}$, no significant differences in EC were observed among roofs with substrates of different thickness, i.e., GRb5 (437.4), GRb10 (357.2), GRb15 (449.1), GRb20 (346.9) and GR5 (611.5), GR10 (618.8), GR15 (616.2) and GR20 (555.6), indicating that the thickness of the substrate had no significant effect on the EC of green roof runoff. However, the EC in the green roof runoff with biochar was lower than that of the green roof runoff without biochar, which indicated that the addition of biochar could reduce the runoff EC. The EC values of the runoff between the GR10 and GRn10 (570.7) were similar, indicating that plant growth did not affect the EC value.

According to Fig. 3c), the concentration of TSS in the green roof runoff was greater than that of rainwater but less than that of AR runoff, which indicated that the green roof had a certain intercepting effect on the TSS in the runoff. The thickness of the substrate, biochar and plants did not significantly affect TSS in runoff.
Nutrients, COD, TOC, and TIC

TP and $\mathrm{NH}_{4}^{+}-\mathrm{N}$ were similarly regulated, and different substrate thickness, biochar and plants did not significantly affect the concentrations in runoff (Fig. 4a and b). However, the average concentration of TP in green roof runoff was higher than that in rainwater, suggesting that green roofs were pollution source of TP. By contrast, the average concentration of $\mathrm{NH}_{4}^{+}-\mathrm{N}$ in green roof runoff was lower than that in rainwater and in the ARs runoff, demonstrating that green roofs were sinks for $\mathrm{NH}_{4}^{+}-\mathrm{N}$. As shown in Fig. $4 \mathrm{C}$ and $\mathrm{D}$ the behavior of $\mathrm{TN}$ and $\mathrm{NO}_{3}^{-}-\mathrm{N}$ was similar. The average concentration of $\mathrm{TN}$ and $\mathrm{NO}_{3}{ }^{-} \mathrm{N}$ in green roof runoff was higher than that in rainwater, illustrating that green roofs were a pollution source of $\mathrm{TN}$ and $\mathrm{NO}_{3}^{-}-\mathrm{N}$. The average concentration of $\mathrm{TN}$ and $\mathrm{NO}_{3}{ }^{-} \mathrm{N}$ in the green roof runoff with biochar was significantly lower than that without biochar, which indicated that the addition of biochar could significantly decrease the concentration of $\mathrm{TN}$ and $\mathrm{NO}_{3}{ }^{-} \mathrm{N}$. Different 

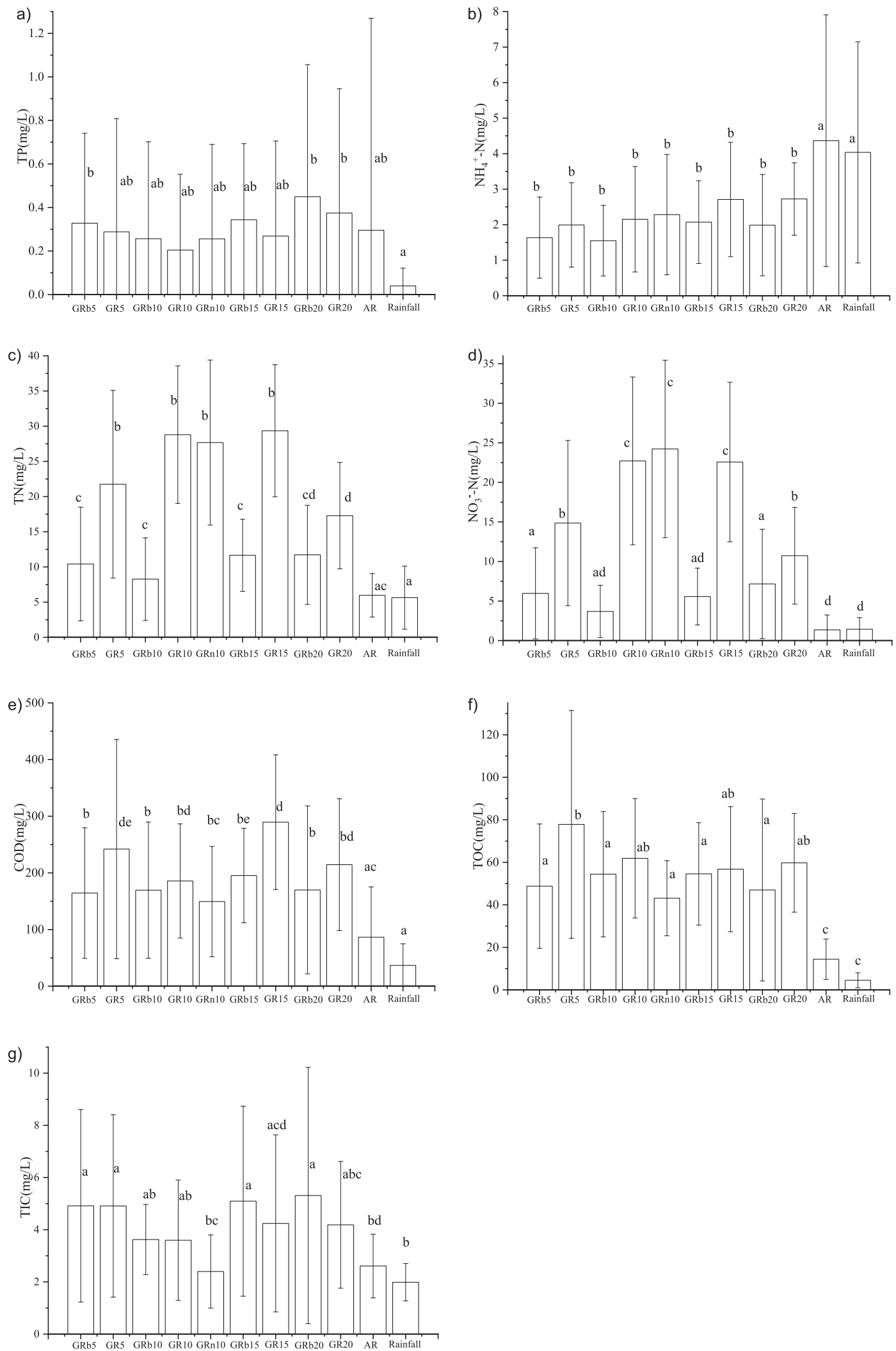

Fig. 4. The average TP, $\mathrm{NH}_{4}^{+}-\mathrm{N}, \mathrm{NO}_{3}^{-}-\mathrm{N}, \mathrm{TN}, \mathrm{COD}, \mathrm{TOC}$ and $\mathrm{TIC}$ concentrations of monitoring rainfall events from the green roof, asphalt roof, and rainfall.

Note: GRb5, GRb10, GRb15 and GRb20 = Green roof with substrate (green roof were filled with the first substrate with biochar) thickness of 5, 10, 15, or $20 \mathrm{~cm}$, respectively; GR5, GR10, GR15 and GR20 = Green roof with substrate (green roof were filled with the second substrate without biochar) thickness of 5,10,15, or $20 \mathrm{~cm}$, respectively; GRn10 = green roof with a $10 \mathrm{~cm}$ thick substrate was filled with the second substrate type and without plants; $\mathrm{AR}=$ asphalt roof.

The values refer to means \pm S.D. The values followed by different letter for green roof, asphalt roof and rainfall designate significantly different at $P<0.05$ level by One-way ANOVA (post-hoc). 
substrate thicknesses and plants did not significantly affect the concentration of $\mathrm{TN}$ and $\mathrm{NO}_{3}{ }^{-} \mathrm{N}$ in runoff.

The variation in COD and TOC was similar in Fig. 4 e) and f). The average concentration of COD
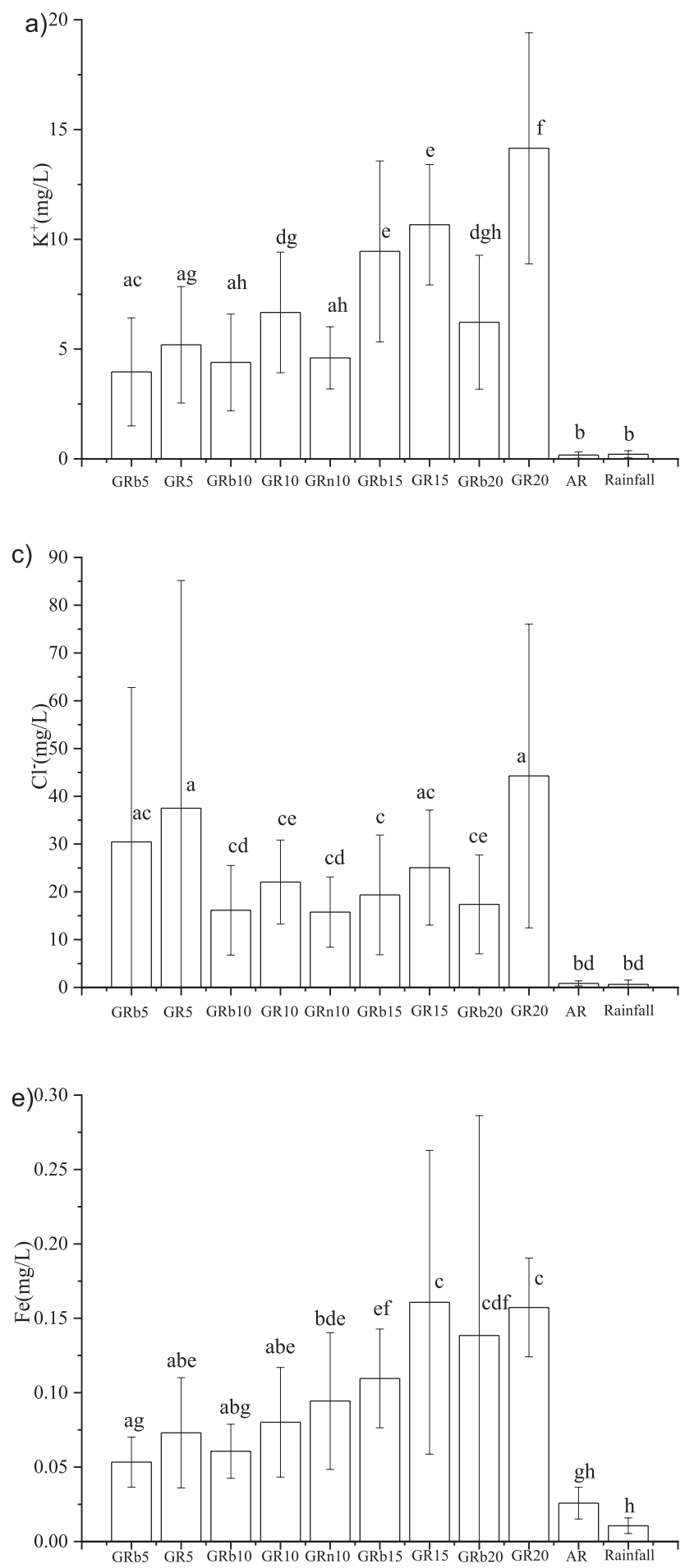

and TOC in green roof runoff was significantly higher than that in rainwater, suggesting that green roofs were a pollution source for COD and TOC. The addition of biochar decreased the COD and
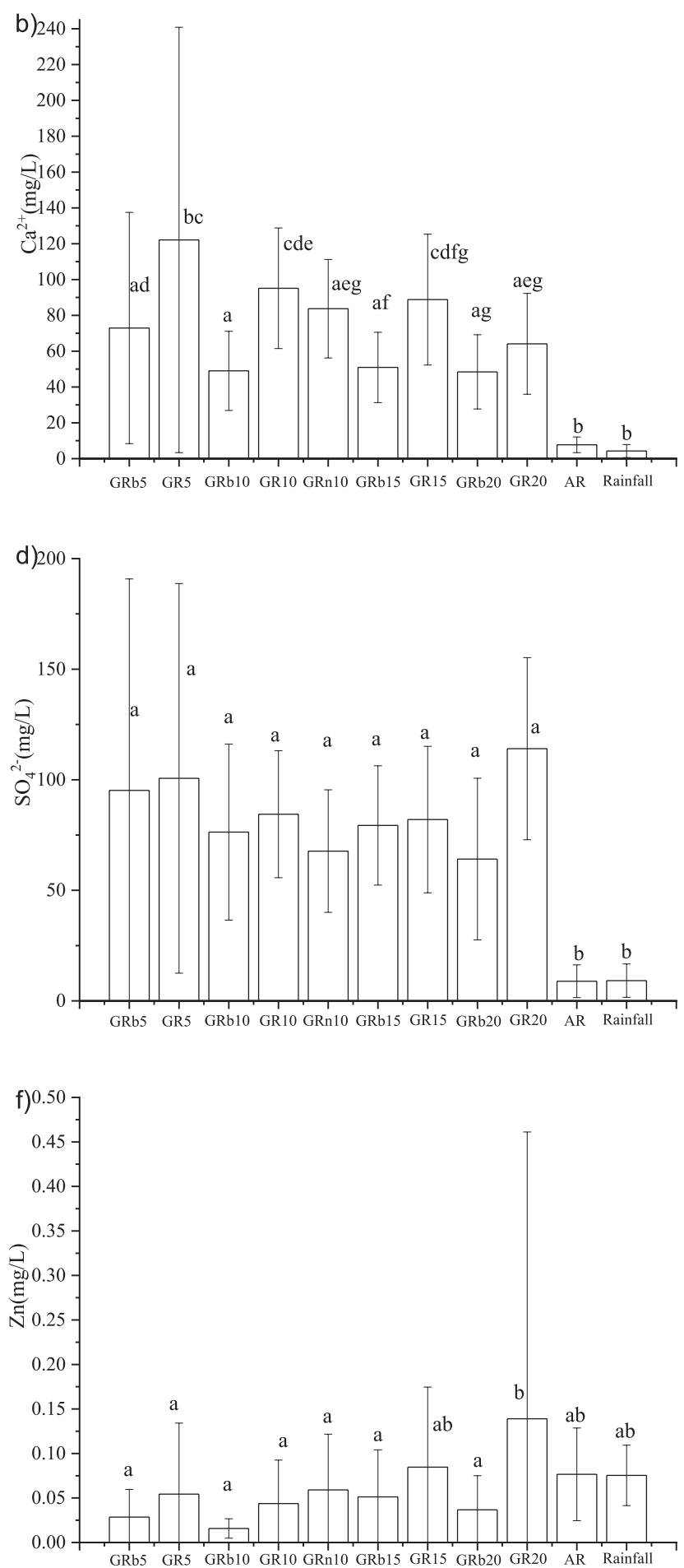

Fig. 5. The average $\mathrm{K}^{+}, \mathrm{Ca}^{2+}, \mathrm{Cl}^{-}, \mathrm{SO}_{4}^{2-}, \mathrm{Fe}$ and $\mathrm{Zn}$ concentrations of monitoring rainfall events from the green roof, asphalt roof, and rainfall.

Note: GRb5, GRb10, GRb15 and GRb20 = Green roof with substrate (green roof were filled with the first substrate with biochar) thickness of 5, 10, 15, or $20 \mathrm{~cm}$, respectively; GR5, GR10, GR15 and GR20 = Green roof with substrate (green roof were filled with the second substrate without biochar) thickness of 5,10,15, or $20 \mathrm{~cm}$, respectively; GRn $10=$ green roof with a $10 \mathrm{~cm}$ thick substrate was filled with the second substrate type and without plants; $\mathrm{AR}=$ asphalt roof.

The values refer to means \pm S.D. The values followed by different letter for green roof, asphalt roof and rainfall designate significantly different at $P<0.05$ level by One-way ANOVA (post-hoc). 
Table 4. Pollutants of which green roofs behave as source or sink when compared with rainwater and asphalt roof.

\begin{tabular}{|c|c|c|c|}
\hline \multicolumn{2}{|c|}{ Green roof } & Rainfall & Asphalt roof \\
\hline \multirow{2}{*}{$\begin{array}{l}\text { Green roof } \\
\text { with biochar }\end{array}$} & Source & $\mathrm{TP}, \mathrm{TOC}, \mathrm{K}^{+}, \mathrm{Ca}^{2+}, \mathrm{Cl}^{-}, \mathrm{SO}_{4}^{2-}, \mathrm{Fe}$ & $\mathrm{K}^{+}, \mathrm{Cl}^{-}, \mathrm{SO}_{4}^{2-}$ \\
\hline & Sink & $\mathrm{TN}, \mathrm{COD}, \mathrm{NO}_{3}^{-}-\mathrm{N}, \mathrm{NH}_{4}^{+}-\mathrm{N}, \mathrm{TSS}, \mathrm{Zn}$ & $\mathrm{TN}, \mathrm{COD}, \mathrm{NO}_{3}^{-}-\mathrm{N}, \mathrm{TP}, \mathrm{NH}_{4}^{+}-\mathrm{N}, \mathrm{TSS}, \mathrm{TIC}, \mathrm{TOC}, \mathrm{Ca}^{2+}, \mathrm{Fe}, \mathrm{Zn}$ \\
\hline \multirow{2}{*}{$\begin{array}{l}\text { Green roof } \\
\text { without biochar }\end{array}$} & Source & $\begin{array}{c}\mathrm{COD}, \mathrm{TP}, \mathrm{TN}, \mathrm{NO}_{3}^{-}-\mathrm{N}, \mathrm{TOC}, \mathrm{K}^{+}, \mathrm{Ca}^{2+} \\
\mathrm{Cl}^{-}, \mathrm{SO}_{4}^{2-}, \mathrm{Fe}\end{array}$ & $\mathrm{TN}, \mathrm{NO}_{3}^{-}-\mathrm{N}, \mathrm{K}^{+}, \mathrm{Cl}^{-}, \mathrm{SO}_{4}^{2-}$ \\
\hline & Sink & $\mathrm{NH}_{4}^{+}-\mathrm{N}, \mathrm{TSS}, \mathrm{Zn}$ & TP, $\mathrm{NH}_{4}^{+}-\mathrm{N}, \mathrm{TSS}, \mathrm{TOC}, \mathrm{TIC}, \mathrm{Ca}^{2+}, \mathrm{Fe}, \mathrm{Zn}$ \\
\hline
\end{tabular}

TOC concentrations in runoff, whereas no prominent influence of substrate thickness was observed. However, the concentrations of COD $(185.8 \mathrm{mg} / \mathrm{L})$ and TOC $(61.9 \mathrm{mg} / \mathrm{L})$ in the runoff of GR10 were higher than those in the runoff of GRn10 (COD $(149.4 \mathrm{mg} / \mathrm{L})$ and TOC $(43.1 \mathrm{mg} / \mathrm{L}))$, demonstrating that plants may increase the concentration of COD and TOC in the runoff. As shown in Fig. 4g), the average concentration of TIC in the green roof runoff was conspicuously higher than that in rainwater, indicating that green roofs released large amounts of TIC into runoff and therefore were a source. The addition of biochar in the substrate may increase the concentration of TIC in runoff, because the TIC in GRb5 (5.21 mg/L), GRb10 (5.12 mg/L), GRb15 $(5.09 \mathrm{mg} / \mathrm{L})$, and GRb20 (5.31 mg/L) runoff was greater than that from GR5 (4.91 mg/L), GR10 (4.29 mg/L), GR15 (4.24 mg/L), and GR20 (4.19 mg/L), respectively. Furthermore, the TIC concentration (4.29 $\mathrm{mg} / \mathrm{L})$ in the GR10 runoff was higher than that of GRn10 $(3.39 \mathrm{mg} / \mathrm{L})$, indicating that plants may also increase the concentration of TIC in runoff.

\section{Ions and Metals}

The concentrations of $\mathrm{K}^{+}, \mathrm{Ca}^{2+}, \mathrm{Cl}^{-}, \mathrm{SO}_{4}^{2-}$, and $\mathrm{Fe}$ in the green roof runoff were significantly higher than those in rainwater and control roof runoff (Fig. 5a-e), demonstrating that green roofs were a source of the ions. However, the concentration of $\mathrm{Zn}$ in green roof runoff was similar to that in rainwater and control roof runoff (Fig. 5f). The substrate with biochar reduced the concentrations of $\mathrm{K}^{+}, \mathrm{Ca}^{2+}, \mathrm{Cl}^{-}, \mathrm{SO}_{4}^{2-}, \mathrm{Fe}$, and $\mathrm{Zn}$ in the runoff. However, plants had no significant effect on the concentrations of $\mathrm{K}^{+}, \mathrm{Ca}^{2+}, \mathrm{Cl}^{-}, \mathrm{SO}_{4}^{2-}, \mathrm{Fe}$, and $\mathrm{Zn}$ in the runoff. Notably, with the increase in the thickness of the substrate layer, the concentrations of $\mathrm{K}^{+}$and $\mathrm{Fe}$ in the green roof runoff increased. This result may be due to the growth of plants increased with substrate thickness, and with the roots of plants more developed, a dominant flow was more easily formed. Moreover, the biochar produced by high temperature has a weak adsorption capacity for cations.

\section{Pollutant Load of Green Roof Runoff}

When the pollutant load of water quality parameters was compared among green roof runoff, control roof runoff, and rainfall (Table 3), the increase in the thickness of the green roof substrate layer did not significantly affect the pollution load of the water quality parameters in the runoff. The green roofs with biochar significantly reduced the pollution load of $\mathrm{TN}$, $\mathrm{TP}, \mathrm{NO}_{3}^{-}-\mathrm{N}, \mathrm{COD}, \mathrm{TOC}$, and TIC in runoff, whereas the contents of TSS, $\mathrm{NH}_{4}^{+}-\mathrm{N}, \mathrm{K}^{+}, \mathrm{Ca}^{2+}, \mathrm{Cl}^{-}, \mathrm{SO}_{4}^{2-}, \mathrm{Fe}$, and $\mathrm{Zn}$ were not affected. In addition, the green roof with plants (GR10) did not affect the pollution load of the water quality parameters in runoff compared with that in GRn10 (without plants and biochar).

When the pollutant load of water quality parameters in the green roof runoff and rainfall was compared (Table 4), the green roofs decreased the total pollution load of $\mathrm{NH}_{4}^{+}-\mathrm{N}$, TSS, TIC, and $\mathrm{Zn}$, acting as a sink, whereas the green roofs were a source of TP, TOC, $\mathrm{K}^{+}$, $\mathrm{Ca}^{2+}, \mathrm{Cl}^{-}, \mathrm{SO}_{4}^{2-}$, and $\mathrm{Fe}$. The addition of biochar in the green roof substrate prominently reduced the pollutant load of TN, COD, and $\mathrm{NO}_{3}^{-}-\mathrm{N}$ in the runoff, acting as a sink. Nevertheless, the green roofs without biochar were a pollution source of $\mathrm{TN}, \mathrm{COD}$, and $\mathrm{NO}_{3}^{-}-\mathrm{N}$ in runoff, demonstrating again that biochar had good purifying effects on TN, COD, and $\mathrm{NO}_{3}^{-}{ }^{-} \mathrm{N}$ in runoff.

When the pollutant load of water quality parameters in the green roof runoff and the control roof runoff was compared (Table 4), all green roofs were shown to be the only the source of $\mathrm{K}^{+}, \mathrm{Cl}^{-}$, and $\mathrm{SO}_{4}^{2-}$ pollution. Similar to the rainwater reference, with the control roofs used as a reference, the green roofs with biochar reduced the $\mathrm{TN}$ and $\mathrm{NO}_{3}{ }^{-} \mathrm{N}$ in the runoff, acting as a sink, whereas the green roofs without biochar were a pollution source.

\section{The Primary Pollution Sources of Green Roof Runoff}

\section{The Primary Pollution Sources of Green Roof Runoff with Nonbiochar Substrate}

Table 5 presents the results that $\mathrm{PCl}$ accounted for $37.36 \%$ of the total variance and had strong and positive loadings on COD, TOC, $\mathrm{NH}_{4}^{+}$, and $\mathrm{Zn}$. The COD and TOC represented the organic pollutants and were generated primarily from peat and asphalt. Mendez et al. (2011) found that an asphalt fiberglass shingle roof was a source of organic matter [32]. In this study, because the waterproof layer of the green roof was made of asphalt felt, the asphalt felt may have been the source of COD and TOC in the green roof runoff. 
The $\mathrm{NH}_{4}^{+}$and $\mathrm{Zn}$ may be from rainfall, because their concentrations were lower than those in rainfall. Thus, PCl can be identified as the organic pollution sources, which were primarily peat, asphalt and rainfall.

PC2 accounted for $16.93 \%$ of the total variance and was closely related to $\mathrm{Cl}^{-}, \mathrm{SO}_{4}^{2-}, \mathrm{Ca}^{2+}$ and EC. Previous research found that the $\mathrm{Cl}^{-}, \mathrm{SO}_{4}{ }^{2-}$ and $\mathrm{Ca}^{2+}$ in green roof runoff mainly came from the substrate materials [4]. In this study, the $\mathrm{EC}$ and concentrations of $\mathrm{Cl}^{-}, \mathrm{SO}_{4}{ }^{2-}$, and $\mathrm{Ca}^{2+}$ in the green roof runoff were significantly higher than those in rainfall and AR runoff. Therefore, the $\mathrm{Cl}^{-}, \mathrm{SO}_{4}^{2-}$, and $\mathrm{Ca}^{2+}$ in green roof runoff were likely primarily from substrate materials (peat and vermiculite). Thus, PC2 can be identified as the ion pollution sources, which were primarily peat and vermiculite.

PC3 accounted for $12.17 \%$ of the total variance and was closely associated with $\mathrm{NO}_{3}^{-}$, TN and TIC. The $\mathrm{NO}_{3}^{-}$and $\mathrm{TN}$ represented the nutrient pollutants and were mainly from peat. Berndtsson (2010) found that the nitrogen in green roof runoff came from soil and roof maintenance (such as the use of fertilizers) [16]. In this study, the concentrations of $\mathrm{NO}_{3}^{-}$and $\mathrm{TN}$ in the green roof runoff of the nonbiochar substrate were significantly higher than those in rainfall and the AR

Table 5. Loadings of 16 selected variables on varimax rotated factors in green roof with biochar substrate.

\begin{tabular}{|c|c|c|c|c|}
\hline \multirow{2}{*}{ Parameters } & \multicolumn{4}{|c|}{ Factors } \\
\hline & $\mathrm{PC} 1$ & $\mathrm{PC} 2$ & PC3 & PC4 \\
\hline $\mathrm{NH}_{4}^{+}-\mathrm{N}$ & 0.874 & 0.298 & 0.011 & 0.046 \\
\hline TOC & 0.815 & 0.248 & -0.020 & 0.110 \\
\hline $\mathrm{Fe}$ & 0.795 & -0.114 & 0.215 & -0.083 \\
\hline $\mathrm{Zn}$ & 0.781 & 0.166 & -0.052 & -0.026 \\
\hline COD & 0.781 & 0.380 & 0.193 & -0.018 \\
\hline $\mathrm{K}^{+}$ & 0.713 & 0.276 & 0.104 & 0.216 \\
\hline TSS & 0.575 & 0.299 & -0.243 & 0.067 \\
\hline $\mathrm{Ca}^{2+}$ & 0.249 & 0.941 & 0.028 & 0.169 \\
\hline $\mathrm{Cl}$ & 0.272 & 0.928 & 0.012 & 0.089 \\
\hline $\mathrm{SO}_{4}^{2-}$ & 0.167 & 0.923 & -0.116 & 0.019 \\
\hline $\mathrm{EC}$ & 0.354 & 0.749 & -0.023 & 0.364 \\
\hline $\mathrm{pH}$ & -0.071 & 0.077 & 0.934 & -0.015 \\
\hline TIC & 0.339 & -0.102 & 0.863 & -0.061 \\
\hline $\mathrm{NO}_{3}^{-}-\mathrm{N}$ & 0.002 & 0.291 & -0.131 & 0.896 \\
\hline $\mathrm{TN}$ & 0.484 & 0.326 & -0.109 & 0.754 \\
\hline TP & -0.157 & -0.135 & 0.294 & 0.389 \\
\hline Eigenvalue & 6.90 & 2.55 & 1.63 & 1.27 \\
\hline$\%$ Total variance & 43.13 & 15.93 & 10.18 & 7.92 \\
\hline Cumulative \% & 43.13 & 59.06 & 69.24 & 77.16 \\
\hline
\end{tabular}

runoff, with no fertilizer applied to the green roofs. In addition, the peat substrate selected contained a high content of nitrogen. Therefore, PC3 can be identified as the nutrients pollution sources and primarily from peat.

PC4 accounted for $7.83 \%$ of the total variance and had strong and positive loadings on $\mathrm{pH}$ and TSS. The $\mathrm{pH}$ was influenced by the physical and chemical properties of the green roof substrate, and the level of TSS was also affected by the comprehensive filtration of the substrate layer of green roofs. Thus, PC4 can be identified as the "physicochemical" sources. PC5 accounted for $6.79 \%$ of the total variance and was closely related to $\mathrm{Fe}$ and $\mathrm{K}^{+}$. The concentrations of $\mathrm{Fe}$ and $\mathrm{K}^{+}$in green roof runoff (nonbiochar substrate) were significantly higher than those in rainfall and AR runoff. Therefore, the $\mathrm{Fe}$ was likely primarily from the vermiculite. Thus, PC5 can be identified as the metal sources and primarily from vermiculite.

\section{The Primary Pollution Sources of Green Roof Runoff with Biochar Substrate}

Compared with the green roofs with nonbiochar substrate, the biochar substrate strongly adsorbed the pollutants and changed the kinds of pollution sources in green roof runoff. As shown in Table 6, PC1 accounted for $43.13 \%$ of the total variance and had strong and positive loadings on $\mathrm{NH}_{4}^{+}, \mathrm{TOC}, \mathrm{Fe}$, and $\mathrm{Zn}$ and moderately positive loadings on COD and TSS. Thus, PC1 identified the organic and metal pollution sources. However, the runoff concentrations of $\mathrm{NH}_{4}^{+}$, TOC, $\mathrm{COD}$, TSS, Fe, and Zn were not significantly different between the green roofs with biochar and nonbiochar substrates. Thus, $\mathrm{PC} 1$ represented a class of pollution sources (organic and metal pollution sources) that were less affected by biochar purification.

PC2 accounted for $15.93 \%$ of the total variance and had strong and positive loadings on $\mathrm{Ca}^{2+}, \mathrm{Cl}^{-}, \mathrm{SO}_{4}^{2-}$ , and $\mathrm{EC}$, thereby representing ion pollution sources. The EC and concentrations of $\mathrm{Ca}^{2+}, \mathrm{Cl}^{-}$, and $\mathrm{SO}_{4}^{2-}$ were significantly lower in the green roof runoff with the biochar substrate than those in the green roof runoff with nonbiochar substrate (Fig. 5a), c), and d)). Thus, PC2 identified the type of pollution source (ion pollution sources) that was greatly affected by biochar purification. PC3 accounted for $10.18 \%$ of the total variance and had strong and positive loadings on $\mathrm{pH}$ and TIC. The concentration of TIC and the $\mathrm{pH}$ values were slightly higher in the green roof runoff with biochar substrate than those in the green roof runoff with nonbiochar substrate (Fig. 4a) and 5g)). Thus, PC3 represented the biochar pollution sources. PC4 accounted for $7.92 \%$ of the total variance and had strong and positive loadings on $\mathrm{NO}_{3}^{-}$and $\mathrm{TN}$, thereby representing nutrient pollution sources. The concentrations of the $\mathrm{NO}_{3}^{-}$and $\mathrm{TN}$ were significantly lower in the green roof runoff with biochar substrate than those in the green roof runoff with nonbiochar substrate (Fig. 5c) and d)). Thus, PC4 identified the type 
Table 6. Loadings of 16 selected variables on varimax rotated factors in green roof with non-biochar substrate.

\begin{tabular}{|c|c|c|c|c|c|}
\hline \multirow{2}{*}{ Parameters } & \multicolumn{5}{|c|}{ Factors } \\
\hline & $\mathrm{PC} 1$ & $\mathrm{PC} 2$ & PC3 & PC4 & PC5 \\
\hline COD & 0.900 & 0.264 & 0.060 & 0.023 & 0.100 \\
\hline $\mathrm{NH}_{4}^{+}$ & 0.812 & 0.097 & 0.026 & -0.101 & 0.347 \\
\hline $\mathrm{Zn}$ & 0.795 & 0.197 & -0.040 & -0.041 & 0.150 \\
\hline TOC & 0.787 & 0.451 & 0.106 & -0.122 & 0.080 \\
\hline $\mathrm{Cl}^{-}$ & 0.258 & 0.892 & -0.049 & 0.054 & 0.171 \\
\hline $\mathrm{SO}_{4}^{2-}$ & 0.219 & 0.868 & 0.189 & -0.188 & 0.177 \\
\hline $\mathrm{Ca}^{2+}$ & 0.418 & 0.724 & 0.405 & 0.026 & -0.107 \\
\hline $\mathrm{EC}$ & 0.404 & 0.543 & 0.517 & 0.138 & 0.069 \\
\hline $\mathrm{NO}_{3}^{-}$ & -0.146 & 0.092 & 0.927 & -0.050 & -0.111 \\
\hline $\mathrm{TN}$ & 0.295 & 0.184 & 0.899 & -0.077 & 0.015 \\
\hline TIC & 0.309 & 0.074 & -0.622 & 0.550 & -0.190 \\
\hline $\mathrm{pH}$ & 0.029 & 0.078 & -0.135 & 0.907 & -0.139 \\
\hline TSS & 0.353 & 0.210 & -0.062 & -0.766 & -0.152 \\
\hline $\mathrm{Fe}$ & 0.393 & -0.136 & -0.126 & -0.222 & 0.797 \\
\hline $\mathrm{K}^{+}$ & 0.227 & 0.296 & 0.310 & 0.055 & 0.774 \\
\hline $\mathrm{TP}$ & 0.019 & 0.261 & -0.235 & 0.047 & 0.387 \\
\hline Eigenvalue & 5.98 & 2.71 & 1.95 & 1.25 & 1.09 \\
\hline$\%$ Total variance & 37.36 & 16.93 & 12.17 & 7.83 & 6.79 \\
\hline Cumulative $\%$ & 37.36 & 54.28 & 66.45 & 74.28 & 81.06 \\
\hline
\end{tabular}

of pollution source (nutrient pollution sources) that was greatly affected by biochar purification.

\section{Discussion}

\section{Factors Affecting Retention Capacity of Green Roofs}

The retention capacity of green roof is affected by many factors, such as atmospheric conditions (e.g. rainfall volume, intensity and duration, atmospheric temperature and humidity, and wind speed, etc.) and characteristics of green roof (substrate components and depths, plant, and the age of roof, etc.) [7]. In this study, we mainly discussed the effect of substrate depths, biochar addition and plants on the retention capacity of green roofs.

\section{Effects of Different Substrate Depths on Runoff Retention Capacity}

The substrate depth is an important factor affecting the runoff retention capacity of a green roof [7]. Normally, the thicker the substrate layer is, the greater the saturation capacity and the better the interception effect on rainfall. Nardini and Crasso [17] found that 12 and $20 \mathrm{~cm}$ substrate modules reduced runoff by 63 and $83 \%$, respectively. The German green roof guidelines also note that the change in runoff retention capacity of green roofs is primarily caused by the substrate at different depths [33]. The conclusions of this study are consistent with those of previous researches. With the increase in substrate depth, the runoff retention rate increased, and the retention rate of GRb15, GRb20, and GRb20 was significantly higher than that of GRb5 and GR5, demonstrating that substrate depth increased the green roof runoff retention rate. However, in the practical application of green roof technology, the substrate depth was limited by the roof bearing capacity [34] and the cost of the management and maintenance; thus, the increase in substrate depth was limited in practice.

\section{Effects of Biochar Addition to the Green Roof Substrate on Retention Runoff Capacity}

Biochar has extremely low solubility, large porosity and specific surface area, and is generally alkaline and highly esterified, containing a carboxylic acid and aromatic structure. These properties give biochar a high adsorption capacity, as well as antioxidant and 
antibiodegradation properties. In previous studies, biochar used as a soil amendment can increase the soil water retention capacity [27]. Cao et al. [35] found that the addition of $40 \%$ biochar (city green waste) to green roof substrate increased the water retention capacity by $52 \%$. In this study, the addition of $10.5 \%$ biochar (coconut shells) to green roof substrate increased the mean runoff retention rate by only $2.3 \%$, which is much less than results from previous research. This result may due to the use of different materials to produce biochar. Previous researchers found that the biochar is made of larger wood materials (it have larger porosity and surface area) and has large water-absorbing capacity [36]. In this study, the biochar was produced from coconut shells (it has smaller porosity and surface area), thus, the water retention capacity of green roof was not significantly increased.

\section{Effects of Plants on Retention Capacity of Green Roof Runoff}

Plants can increase the runoff retention capacity of a green roof through the consumption and transpiration of water and the interception of water by the branches and leaves. In a comparative experiment in Missouri, USA, Harper et al. [18] found that plants significantly reduce the runoff from green roofs. Runoff was reduced by $40 \%$ on green roofs without plants but by $60 \%$ on green roofs with plants. Plant evaporation capacity is also a key factor affecting the green roof runoff retention capacity, and as the transpiration of plants increases, the interception capacity also increases. With an increase in the water consumed by plant evapotranspiration, the space available in soil increased, which results in increasing rainfall interception [37]. In this study, the runoff retention rate of a green roof with plants GR10 $(52.71 \%)$ was slightly greater than that without plants GRn10 (48.41\%), indicating that a planted green roof can increase the runoff retention rate to a certain extent. However, the effect of plants was not significant, and this result may be related to the type of plant used (Sedum lineare). Nagase and Dunnett [38] found that the green roof runoff retention capacity was distinct for different types of plants. In this study, the type of plant used, Sedum lineare, was small with strong waterholding ability and weak transpiration. Therefore, the increase in green roof runoff retention capacity with plants was not significant in this study.

\section{Factors Affecting Runoff Quality of Green Roofs}

The effect of green roof on runoff water quality is a hot issue concerned by scholars. Previous researches have focused on the effect of rainfall characteristics on runoff water quality of green roofs. However, the influence of substrate components on runoff water quality has not been deeply analyzed. In this study, we focused on discussing the effect of substrate depths, biochar addition and plants on the runoff water quality of green roofs.

\section{Effects of Different Substrate Depths on Runoff Water Quality}

In general, the main contamination sources of green roof runoff are atmospheric dry and wet deposition and contaminants contained in the green roof substrate. Therefore, an increase in the depth of green roof substrate may increase the total pollutant amounts carried in green roof runoff, but an increase in depth can also intercept more rainwater, resulting in less rainfall runoff. In this study, the increase in substrate depth did not significantly affect the concentration of water quality parameters in the runoff. However, with the increase in substrate depth, the concentrations of $\mathrm{K}^{+}$and $\mathrm{Fe}$ in the green roof runoff increased, which may be related to with the substrate depth increased, the growth of the plants became better and better, and the plant roots were more developed, and leading to the dominant flow was easily formed. In addition, the adsorption capacity of biochar produced by high temperature for cations was weak. Seidl et al. [25] found that a $16 \mathrm{~cm}$ roof systematically showed higher nutrient and organic carbon concentrations than that of $6 \mathrm{~cm}$ roof, although the SS content was lower. In this study, similar results were not observed, which may be due to different substrate types, or due to the study monitored fewer rainfall events $(n=4)$ and the absence of statistical tests.

With the increase in interception capacity as substrate depth increased, the total pollution load of the green roof runoff water quality parameters was reduced. In this study, compared with rainfall, and only considering the concentration of green roof runoff water quality parameters, the green roofs were a sink for only $\mathrm{NH}_{4}^{+}-\mathrm{N}$ and a pollution source for the other water quality parameters. When considering the pollution load, green roofs were a sink for $\mathrm{NH}_{4}^{+}-\mathrm{N}, \mathrm{TSS}, \mathrm{TIC}$, and $\mathrm{Zn}$ and a pollution source for TP, TOC, $\mathrm{K}^{+}, \mathrm{Ca}^{2+}$, $\mathrm{Cl}^{-}, \mathrm{SO}_{4}^{2-}$, and $\mathrm{Fe}$. Therefore, with the increase in the depth of the green roof substrate can decrease the total pollutant load of runoff, and as a result, the contribution of urban nonpoint source pollution to urban receiving water bodies can be reduced.

\section{Effects of Adding Biochar to the Green Roof Substrate on Runoff Water Quality}

As a soil amendment, biochar can absorb pollutants in soil [39, 40] and reduce soil nutrient (nitrogen and phosphorus) losses. However, whether biochar can improve the water quality of green roof runoff has not been studied intensively. In this study, the biochar significantly reduced the $\mathrm{EC}$ and concentrations $\mathrm{TN}$, $\mathrm{NO}_{3}^{-}-\mathrm{N}, \mathrm{NH}_{4}^{+}-\mathrm{N}, \mathrm{COD}, \mathrm{TOC}, \mathrm{K}^{+}, \mathrm{Ca}^{2+}, \mathrm{Cl}^{-}, \mathrm{SO}_{4}{ }^{2-}, \mathrm{Fe}$, and $\mathrm{Zn}$ in green roof runoff. Therefore, based on these results, biochar was effective on purifying most water 
quality parameters of green roof runoff. The results are similar to those of Beck et al. [27], who found that biochar significantly reduced the concentration of $\mathrm{TN}$, $\mathrm{NO}_{3}^{-}-\mathrm{N}$ and TOC in green roof runoff. However, in our study, the concentration of TP was not significantly different between the substrates with and without biochar in the runoff. This result is different from previous studies. Researcher found that biochar could reduce TP release in green roof runoff by $20-52 \%$ [27]. One possible explanation is that the initial concentration of TP in the substrate was different in the two studies. In Beck study, the initial concentration of TP was significant higher $(10.3-22.1 \mathrm{mg} / \mathrm{L})$ than that in this study (the mean concentration of TP were 0.04 and $0.44 \mathrm{mg} / \mathrm{L}$ in the rain and green roof runoff, respectively). This difference may have led to reduce adsorption capacity of biochar for TP in the current study. To sum up, the addition of biochar to green roof substrates can improve the water holding capacity and purify the water quality of runoff.

\section{Effects of Plants on Runoff Water Quality of Green Roof}

Relatively few studies have examined whether plants decrease or increase the concentrations of water quality parameters in green roof runoff. On one hand, plant growth requires that nutrients be absorbed from the soil, which in turn reduces the amount of nutrients in the runoff; on the other hand, the decomposition of plant roots and litter may increase the concentrations of nutrients and organic pollutants in the soil. In this study, although the plants did not significantly affect the concentrations of water quality parameters in green roof runoff, compared with GRn10, the contents of COD, TOC, and TIC in GR10 runoff were increased 36.34, 18.78, and $1.20 \mathrm{mg} / \mathrm{L}$, respectively. This result may be explained by the decay of plant roots and litter increasing organic pollutant contents in the substrate.

\section{Conclusions}

Based on 93 rainfall events, this research investigated the effects of green roof on runoff quality and quantity, and identified the pollution sources. The water quality parameters of $\mathrm{pH}, \mathrm{EC}, \mathrm{TN}, \mathrm{NH}_{4}^{+}-\mathrm{N}, \mathrm{NO}_{3}{ }^{-}$ -N, TP, COD, TSS, TOC, TIC, $\mathrm{Cl}^{-}, \mathrm{SO}_{4}^{2-}, \mathrm{K}^{+}, \mathrm{Ca}^{2+}, \mathrm{Fe}$, and $\mathrm{Zn}$ were measured in green roof runoff, $\mathrm{AR}$ runoff, and rainfall samples, and the following conclusions were reached.

The substrate depth significantly increased the green roof runoff retention rate. The addition of biochar in the substrate and planted vegetable increased the retention rate of green roof runoff. The monthly variation in the runoff retention rate of green roofs was primarily affected by rainfall volume.

Based on the analysis of runoff water quality, the increase in substrate depth did not significantly affect the concentration of water quality parameters. The biochar addition significantly reduced the $\mathrm{EC}$ and concentrations of $\mathrm{TN}, \mathrm{NO}_{3}^{-}-\mathrm{N}, \mathrm{NH}_{4}^{+}-\mathrm{N}, \mathrm{COD}, \mathrm{TOC}, \mathrm{K}^{+}$, $\mathrm{Ca}^{2+}, \mathrm{Cl}^{-}, \mathrm{SO}_{4}^{2-}, \mathrm{Fe}$, and $\mathrm{Zn}$ in the runoff from the roof, however, it leads to the increase of the concentration of TIC in runoff. In addition, although plants did not significantly affect the concentration of water quality parameters, vegetation decomposition contributed to COD, TOC, and TIC contents in green roof runoff.

Based on the comparison of the pollutant load of water quality parameters in the green roof runoff and rainfall, the green roofs were a trap for $\mathrm{NH}_{4}^{+}-\mathrm{N}$, TSS, $\mathrm{TIC}$, and $\mathrm{Zn}$, whereas the green roofs were a source of TP, TOC, $\mathrm{K}^{+}, \mathrm{Ca}^{2+}, \mathrm{Cl}^{-}, \mathrm{SO}_{4}{ }^{2-}$, and $\mathrm{Fe}$. Notably, the addition of biochar in the green roof substrate prominently reduced the pollution load of $\mathrm{TN}, \mathrm{COD}$, and $\mathrm{NO}_{3}{ }^{-} \mathrm{N}$ in the runoff, creating a sink for these compounds. When the pollutant loads of the green roofs and the control roofs were compared, green roofs were a pollution source for $\mathrm{K}^{+}, \mathrm{Cl}^{-}$, and $\mathrm{SO}_{4}^{2-}$. The green roofs with biochar were sinks for $\mathrm{TN}$ and $\mathrm{NO}_{3}^{-}-\mathrm{N}$; whereas the green roofs without biochar were a pollution source for these nutrients.

PCA was used to identify the main pollution sources of green roof runoff for the two types of substrate. In the runoff from green roofs with the nonbiochar substrate, the main pollution sources were peat, asphalt, and rainfall for the organic pollutants, peat and vermiculite for the ion pollution, peat for the nutrient pollution, the integrated impact of several sources for physicochemical effects, and vermiculite for metal pollution. However, in the runoff from green roofs with the biochar substrate, the pollution sources were severely affected by biochar. For the different sources, the organic and metal pollution sources were less adsorbed by biochar, whereas the ion and nutrient pollution sources were greatly adsorbed by biochar. The biochar itself was also a source of pollution.

In conclusion, green roofs could significantly detain the rainfall runoff, thus, it could reduce the risk of urban waterlogging. However, the water quality of green roof runoff is seriously affected by the substrate. Although biochar can purify and improve the quality of water in runoff and can add to the runoff retention capacity of green roofs, it also increases the concentration of TIC in runoff. Thus, future studies should screen for biochar with strong runoff retention capacity and high water purification potential. Based on these results, we suggest that the material selection for the green roof matrix is very important for the ecological benefits of green roof. In addition, these results provide a scientific basis for the design and application of green roofs to manage and control urban storm runoff.

\section{Acknowledgements}

The study was funded by the open funds of state key laboratory of urban and region ecology of China (No. 
SKLURE2019-2-3), the Projects of China Geological Survey, China (No. DD20190336 and DD20190331), and the Commissioned Projects Institute of Land Survey and Planning of China (No. B202012).

\section{Conflict of Interest}

The authors declare no conflict of interest.

\section{References}

1. BERNDTSSON J.C., BENGTSSON L., JINNO K. Runoff water quality from intensive and extensive vegetated roofs. Ecological Engineering 35 (3), 369, 2009.

2. STOVIN V., POE S., BERRETTA C. A modelling study of long term green roof retention performance. Journal of Environmental Management, 131 (1), 206, 2013.

3. TODOROV D., DRISCOLL C.T., TODOROVA S., MONTESDEOCA, M. Water quality function of an extensive vegetated roof. Science of the Total Environment, 625, 928, 2018.

4. VIJAYARAGHAVAN K., JOSHI U.M., BALASUBRAMANIAN R. A field study to evaluate runoff quality from green roofs. Water research, 46 (4), 1337, 2012.

5. RAZZAGHMANESH M., BEECHAM S., SALEMI T. The role of green roofs in mitigating Urban Heat Island effects in the metropolitan area of Adelaide, South Australia. Urban Forestry \& Urban Greening, 15, 89, 2016.

6. TAN C.L., TAN P.Y., WONG N.H., TAKASUNA H., KUDO T., TAKEMASA Y., LIM C.V.J., HUI X.V.C. Impact of soil and water retention characteristics on green roof thermal performance. Energy \& Buildings, 152, 830, 2017.

7. ZHANG Q., MIAO L., WANG X., LIU D., ZHU L., ZHOU B., SUN J., LIU J. The capacity of greening roof to reduce stormwater runoff and pollution. Landscape \& Urban Planning, 144 (1), 142, 2015.

8. CONNELlY M., HODGSON M. Experimental investigation of the sound transmission of vegetated roofs. Applied Acoustics, 74 (10), 1136, 2013.

9. HAO N., CORRIE C., JITI Z., PETER A. Scaling of economic benefits from green roof implementation in Washington, DC. Environmental science \& technology, 44 (11), 4302, 2010.

10. Benvenuti S. Wildflower green roofs for urban landscaping, ecological sustainability and biodiversity. Landscape \& Urban Planning, 124 (4), 151, 2014.

11. MENTENS J., RAES D., HERMY M. Green roofs as a tool for solving the rainwater runoff problem in the urbanized 21st century? Landscape \& Urban Planning, 77 (3), 217, 2016.

12. LAMERA C., BECCIU G., RULLI M.C., ROSSO R. Green Roofs Effects on the Urban Water Cycle Components. Procedia Engineering, 70, 988, 2014.

13. NAWAZ R., MCDONALD A., POSTOYKO S. Hydrological performance of a full-scale extensive green roof located in a temperate climate. Ecological Engineering, 82, 66, 2015.

14. CIPOLLA S.S., MAGLIONICO M., STOJKOV I. A longterm hydrological modelling of an extensive green roof by means of SWMM. Ecological Engineering, 95, 876, 2016.
15. CARPENTER C.M.G., TODOROV D., DRISCOLL C.T., MONTESDEOCA M. Water quantity and quality response of a green roof to storm events: Experimental and monitoring observations. Environmental Pollution, 218, 664, 2016.

16. BERNDTSSON J.C. Green roof performance towards management of runoff water quantity and quality: A review. Ecological Engineering, 36 (4), 351, 2010.

17. NARDINI A., CRASSO M. Influence of substrate depth and vegetation type on temperature and water runoff mitigation by extensive green roofs: shrubs versus herbaceous plants. Urban Ecosystems, 15 (3), 697, 2012.

18. HARPER G.E., LIMMER M.A., SHOWALTER W.E., BURKEN J.G. Nine-month evaluation of runoff quality and quantity from an experiential green roof in Missouri, USA. Ecological Engineering, 78, 127, 2015.

19. GETTER K.L., ROWE D.B., ANDRESEN J.A. Quantifying the effect of slope on extensive green roof stormwater retention. Ecological Engineering, 31 (4), 225, 2007.

20. BEECHAM S., RAZZAGHMANESH M. Water quality and quantity investigation of green roofs in a dry climate. Water research, 70 (C), 370, 2015.

21. CARTER T.L., RASMUSSEN T.C. Hydrologic behavior of vegetated roofs. Jawra Journal of the American Water Resources Association, 42 (5), 1261, 2010.

22. GUO J., ZHANG Y., CHE S. Performance analysis and experimental study on rainfall water purification with an extensive green roof matrix layer in Shanghai, China. Water Science and Technology, 77 (3-4), 670, 2018.

23. LI L., LIU X. Application of Green Roof in Relieving Urban Waterlogging: A Review. Journal of Landscape Research, 77, 79, 2017

24. CHEN C.F. Performance evaluation and development strategies for green roofs in Taiwan: A review. Ecological Engineering, 52 (2), 51, 2013.

25. SEIDL M., GROMAIRE M.C., SAAD M., GOUVELLO B.D. Effect of substrate depth and rain-event history on the pollutant abatement of green roofs. Environmental Pollution, 183 (2), 195, 2013.

26. KUOPPAMAKI K., HAGNER M., LEHVAVIRTA S., SETALA H. Biochar amendment in the green roof substrate affects runoff quality and quantity. Ecological Engineering, 88, 1, 2016.

27. BECK D.A., JOHNSON G.R., SPOLEK G.A. Amending greenroof soil with biochar to affect runoff water quantity and quality. Environmental Pollution, 159 (8-9), 2111, 2011.

28. QIU D.Y., PENG H.Y., LI T., QI Y. Application of stabilized sludge to extensive green roofs in Shanghai: Feasibility and nitrogen leaching control. Science of the Total Environment, 732, 138898, 2020.

29. ZHANG Q.Q., MIAO L.P., WANG H.W., WANG L. Analysis of the effect of green roof substrate amended with biochar on water quality and quantity of rainfall runoff. Environmental Monitoring and Assessment, 191, 304, 2019.

30. State Environment Protection Agency of China (SEPAC). Methods of monitoring and analysis for water and wastewater ( th $^{\text {th }}$ ed.). Beijing: China Environmental Science Press (in Chinese), 2002.

31. LIU C.W., LIN K.H., KUO Y.M. Application of factor analysis in the assessment of groundwater quality in a blackfoot disease area in Taiwan. Science of the Total Environment, 313, 77, 2003. 
32. MENDEZ C.B., KLENZENDORF J.B., AFSHAR B.R., SIMMONS M.T., BARRETT M.E., KINNEY K.A., KIRISITS M.J. The effect of roofing material on the quality of harvested rainwater. Water research, 45 (5), 2049, 2011.

33. FLL. Guideline for the Planning, Execution and Upkeep of Green-Roof Sites. Forschungsgesellschaft Landschaftsentwicklung Landschaftsbau, Bonn, Germany, 2008.

34. DUNNETT N., NAGASE A., HALLAM A. The dynamics of planted and colonising species on a green roof over six growing seasons 2001-2006: Influence of substrate depth. Urban Ecosystems, 11 (4), 373, 2008.

35. CAO C.T.N., FARRELL C., KRISTIANSEN P.E., RAYNER J.P. Biochar makes green roof substrates lighter and improves water supply to plants. Ecological Engineering, 71, 368, 2014.

36. NOVAK J.M., BUSSCHER W.J. Selection and Use of Designer Biochars to Improve Characteristics of Southeastern USA Coastal Plain Degraded Soils, 2013.
37. ZHANG Z., SZOTA C., FLETCHER T.D., NSG W., WERDIN J., FARRELL C. Influence of plant composition and water use strategies on green roof stormwater retention. Science of the Total Environment, 625, 775, 2018.

38. NAGASE A., DUNNETT N. Amount of water runoff from different vegetation types on extensive green roofs: Effects of plant species, diversity and plant structure. Landscape \& Urban Planning, 104 (3-4), 0, 2012.

39. CAO X.D., MA L., GAO B., HARRIS W. Dairy-manure derived biochar effectively sorbs lead and atrazine. Environmental science \& technology, 43 (9), 3285, 2009.

40. LUKE B., EDUARDO M.J., GOMEZ-EYLES J.L. Effects of biochar and greenwaste compost amendments on mobility, bioavailability and toxicity of inorganic and organic contaminants in a multi-element polluted soil. Environmental Pollution, 158 (6), 2282, 2010. 


\section{Supplementary Material}

Table S1. Several physico-chemical properties of the substrates.

\begin{tabular}{|c|c|c|c|c|}
\hline Substrate composition & $\begin{array}{c}\text { Organic matter } \\
(\%)\end{array}$ & $\begin{array}{c}\text { Bulk density } \\
\left(\mathrm{g} \cdot \mathrm{cm}^{-3}\right)\end{array}$ & $\begin{array}{c}\text { Available phosphorus } \\
\left(\mathrm{mg} \cdot \mathrm{kg}^{-1}\right)\end{array}$ & $\begin{array}{c}\text { Alkali-hydrolyzed nitrogen } \\
\left(\mathrm{mg} \cdot \mathrm{kg}^{-1}\right)\end{array}$ \\
\hline Peat soil & $60.31 \%$ & 0.5 & 16.4 & 8.43 \\
\hline Perlite & $0.12 \%$ & 0.16 & - & - \\
\hline Vermiculite & $19.31 \%$ & 0.13 & - & - \\
\hline Sawdust & $50.45 \%$ & 0.19 & - & - \\
\hline
\end{tabular}

Table S2. Several physico-chemical properties of the coconut shell biochar.

\begin{tabular}{|c|c|c|c|c|c|c|}
\hline $\mathrm{pH}$ & $\begin{array}{c}\text { Particle size } \\
(\mathrm{mm})\end{array}$ & $\begin{array}{c}\text { Ash } \\
(\%)\end{array}$ & $\begin{array}{c}\text { Moisture } \\
(\%)\end{array}$ & $\begin{array}{c}\text { Apparent density } \\
(\mathrm{g} / \mathrm{mL})\end{array}$ & $\begin{array}{c}\text { Iodine adsorption } \\
\text { value }(\mathrm{mg} / \mathrm{g})\end{array}$ & $\begin{array}{c}\text { Methylene blue adsorption rate } \\
(\mathrm{mL} / \mathrm{g})\end{array}$ \\
\hline 6.5 & $2-4$ & 3.7 & 3.7 & 0.47 & 959 & 118 \\
\hline
\end{tabular}

Table S3. Rainfall characteristics for the monitored 93 rainfall events.

\begin{tabular}{|c|c|c|c|c|}
\hline Monitored events & $\mathrm{RV}(\mathrm{mm})$ & RD (Min) & $\operatorname{ADWP}(\mathrm{h})$ & MRI (mm/Min) \\
\hline $2016-4-29$ & 0.8 & 92 & 11.7 & 0.01 \\
\hline $2016-5-3$ & 2.6 & 197 & 98.3 & 0.100 \\
\hline $2016-5-13$ & 13.5 & 1162 & 247.4 & 0.007 \\
\hline $2016-5-23$ & 1.2 & 7 & 214.4 & 0.2 \\
\hline $2016-6-5$ & 0.9 & 200 & 305.4 & 0.05 \\
\hline 2016-6-13 & 16.2 & 238 & 200.6 & 0.8 \\
\hline 2016-6-14 & 6.9 & 212 & 11.9 & 0.40 \\
\hline $2016-6-28$ & 2.5 & 50 & 206.0 & 0.40 \\
\hline 2016-6-30 & 2.6 & 525 & 35.3 & 0.15 \\
\hline $2016-7-4$ & 4.4 & 48 & 93.3 & 1.20 \\
\hline $2016-7-5$ & 19.0 & 206 & 18.5 & 3.00 \\
\hline $2016-7-9$ & 6.7 & 209 & 84.7 & 0.90 \\
\hline 2016-7-12 & 18.5 & 324 & 69.5 & 0.50 \\
\hline 2016-7-14 & 31.4 & 953 & 47.3 & 0.30 \\
\hline 2016-7-19 & 266.9 & 2925 & 46.6 & 1.02 \\
\hline $2016-7-24$ & 29.2 & 293 & 37.1 & 0.72 \\
\hline $2016-7-28$ & 1.2 & 32 & 88.1 & 0.10 \\
\hline 2016-7-30 & 1.0 & 68 & 48.3 & 0.10 \\
\hline $2016-8-5$ & 1.9 & 100 & 135.1 & 0.10 \\
\hline 2016-8-8 & 10.9 & 80 & 31.0 & 0.30 \\
\hline 2016-8-12 & 8.5 & 187 & 83.9 & 0.88 \\
\hline $2016-8-13$ & 31.6 & 73 & 20.9 & 1.20 \\
\hline 2016-8-14 & 15.8 & 585 & 8.9 & 0.56 \\
\hline 2016-8-15 & 7.1 & 944 & 12.3 & 0.08 \\
\hline $2016-9-7$ & 5.6 & 285 & 324.7 & 0.34 \\
\hline
\end{tabular}


Table S3. Continued.

\begin{tabular}{|c|c|c|c|c|}
\hline 2016-9-10 & 1.2 & 54 & 76.1 & 0.04 \\
\hline $2016-9-17$ & 22.4 & 788 & 172.0 & 0.24 \\
\hline 2016-9-19 & 1.1 & 81 & 15.4 & 0.12 \\
\hline 2016-10-7 & 7.8 & 236 & 7.3 & 0.06 \\
\hline 2016-10-15 & 2.5 & 992 & 192.8 & 0.040 \\
\hline $2016-10-20$ & 19.1 & 944 & 112.5 & 0.120 \\
\hline $2016-10-21$ & 0.5 & 292 & 8.3 & 0.013 \\
\hline $2016-10-22$ & 9.6 & 1090 & 17.1 & 0.080 \\
\hline $2016-10-24$ & 1.1 & 172 & 32.6 & 0.020 \\
\hline $2016-10-27$ & 17.9 & 1163 & 61.4 & 0.080 \\
\hline $2016-11-6$ & 2.9 & 671 & 234.4 & 0.020 \\
\hline $2016-11-20$ & 1.9 & 930 & 325.1 & 0.007 \\
\hline $2016-11-22$ & 0.9 & 111 & 24.0 & 0.010 \\
\hline $2016-12-21$ & 4.9 & 376 & 682.7 & 0.060 \\
\hline $2016-12-21$ & 0.5 & 308 & 11.5 & 0.002 \\
\hline $2016-12-26$ & 0.3 & 99 & 97.5 & 0.003 \\
\hline $2016-12-26$ & 0.5 & 50 & 6.5 & 0.010 \\
\hline $2017-1-5$ & 0.7 & 241 & 242.2 & 0.004 \\
\hline $2017-1-7$ & 0.6 & 302 & 41.9 & 0.005 \\
\hline $2017-2-22$ & 5.6 & 165 & 1096.6 & 0.060 \\
\hline $2017-3-22$ & 1.6 & 417 & 675.0 & 0.020 \\
\hline $2017-3-23$ & 3.6 & 566 & 19.5 & 0.040 \\
\hline $2017-3-24$ & 0.6 & 57 & 11.5 & 0.040 \\
\hline $2017-3-28$ & 3.8 & 305 & 83.1 & 0.140 \\
\hline $2017-3-30$ & 0.4 & 51 & 60.9 & 0.010 \\
\hline 2017-4-4 & 8.9 & 1028 & 111.9 & 0.060 \\
\hline $2017-4-8$ & 13.6 & 951 & 67.1 & 0.100 \\
\hline $2017-4-13$ & 2.8 & 480 & 113.3 & 0.240 \\
\hline $2017-5-3$ & 6.7 & 127 & 478.5 & 0.300 \\
\hline $2017-5-22$ & 11.5 & 608 & 448.0 & 0.060 \\
\hline $2017-5-30$ & 7.4 & 119 & 188.3 & 0.120 \\
\hline $2017-6-2$ & 0.8 & 9 & 67.2 & 0.067 \\
\hline $2017-6-5$ & 0.8 & 62 & 77.4 & 0.020 \\
\hline 2017-6-12 & 3.6 & 544 & 164.0 & 0.160 \\
\hline 2017-6-13 & 2.8 & 479 & 6.4 & 0.100 \\
\hline $2017-6-21$ & 10.4 & 171 & 190.2 & 1.100 \\
\hline $2017-6-22$ & 7.3 & 1028 & 8.8 & 0.060 \\
\hline $2017-6-23$ & 0.5 & 32 & 18.9 & 0.020 \\
\hline $2017-6-25$ & 1.0 & 93 & 48.8 & 0.020 \\
\hline $2017-7-4$ & 0.6 & 474 & 203.5 & 0.040 \\
\hline $2017-7-6$ & 17.6 & 458 & 33.3 & 0.480 \\
\hline
\end{tabular}


Table S3. Continued.

\begin{tabular}{|c|c|c|c|c|}
\hline $2017-7-9$ & 6.7 & 146 & 79.3 & 0.500 \\
\hline $2017-7-11$ & 6.3 & 112 & 46.8 & 0.500 \\
\hline $2017-7-15$ & 17.6 & 244 & 93.8 & 0.700 \\
\hline $2017-7-17$ & 37.6 & 114 & 49.8 & 1.040 \\
\hline $2017-7-18$ & 3.3 & 39 & 12.2 & 0.140 \\
\hline $2017-7-20$ & 1.5 & 154 & 56.4 & 0.040 \\
\hline $2017-7-21$ & 51.7 & 893 & 8.5 & 1.120 \\
\hline $2017-7-24$ & 7.1 & 135 & 54.3 & 0.680 \\
\hline $2017-7-25$ & 4.5 & 97 & 24.4 & 0.100 \\
\hline $2017-7-26$ & 23.3 & 281 & 19.8 & 0.880 \\
\hline $2017-7-27$ & 0.6 & 164 & 19.7 & 0.008 \\
\hline $2017-7-28$ & 12.2 & 1430 & 19.4 & 0.040 \\
\hline $2017-8-4$ & 2.8 & 15 & 157.3 & 0.320 \\
\hline $2017-8-5$ & 15.3 & 58 & 16.4 & 0.720 \\
\hline $2017-8-11$ & 9.6 & 32 & 149.5 & 0.420 \\
\hline $2017-8-12$ & 17.6 & 528 & 17.5 & 0.700 \\
\hline $2017-8-13$ & 1.3 & 44 & 22.4 & 0.080 \\
\hline $2017-8-15$ & 1.4 & 61 & 44.4 & 0.100 \\
\hline $2017-8-18$ & 6.8 & 514 & 58.8 & 0.180 \\
\hline $2017-8-19$ & 8.7 & 723 & 11.1 & 0.580 \\
\hline $2017-8-22$ & 3.2 & 18 & 76.1 & 0.300 \\
\hline $2017-8-26$ & 53.2 & 3164 & 92.4 & 0.220 \\
\hline $2017-9-21$ & 3.8 & 61 & 577.6 & 0.400 \\
\hline $2017-10-2$ & 7.7 & 1145 & 254.2 & 0.040 \\
\hline $2017-10-7$ & 105.3 & 4603 & 99.1 & 0.160 \\
\hline $2017-10-17$ & 7.1 & 998 & 241.0 & 0.040 \\
\hline $2017-10-25$ & 1.8 & 406 & 170.2 & 0.020 \\
\hline
\end{tabular}

Note: $\mathrm{RV}=$ Rainfall volume; $\mathrm{ADWP}=$ Antecedent dry weather period; $\mathrm{RD}=$ Rainfall duration; $\mathrm{MRI}=$ Maximum rainfall intensity

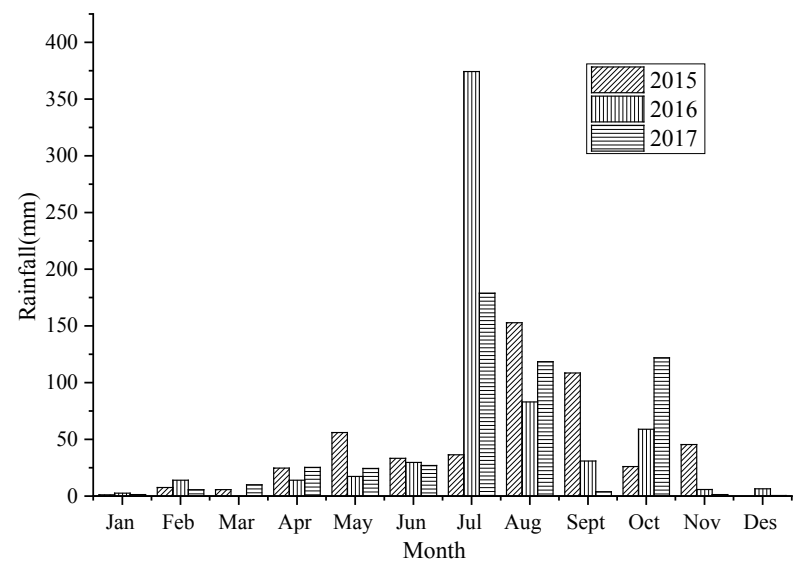

Fig. S1. Temporal variations of rainfall during 2015-2017. 
